\title{
أسس إصلاح التفسير في التحرير والتنوير
} علي محمد أسعد"

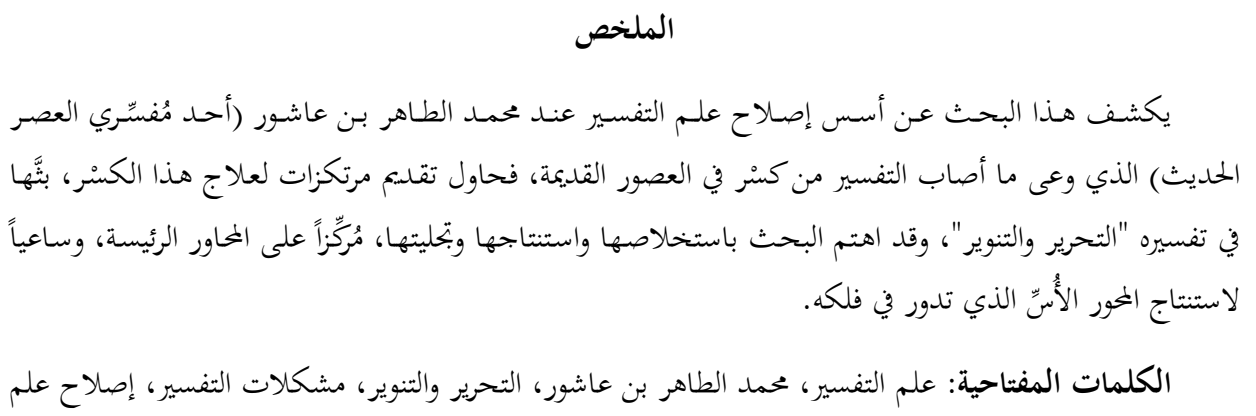

\section{Foundation of the Reform of the Quran'ic exegesis in Ibn 'Ashur's Al-Tahrir and Al-Tanwir}

\begin{abstract}
This study reveals the foundations of the reform of Qura'nic exegesis of Muhammad Al-Tahir ibn 'Ashur, one of the contemporary interpreters of the Qur'an. Ibn 'Ashur displayed awareness of the problems related to the Quran'ic interpretations in history. He provided foundations to address these problems, and included these solutions in his interpretation of the Qur'an: Al-Tahrir wa Al-Tanwir (Liberation and Enlightenment). The study has deduced these foundations, by focusing on the main themes and by seeking to derive the central theme of the work.
\end{abstract}

Keywords: Qur'an exegesis, Muhammad Al-Tahir ibn Ashur, alTahrir wa al-Tanwir, problems of exegesis, Reform of Exegesis.

$$
\begin{aligned}
& \text { ” دكتوراه في التفسير وعلوم القرآن، جامعة الزيتونة بتونس، ع . . بام، أستاذ مشـارك في جامعة العلوم الإسـامية }
\end{aligned}
$$

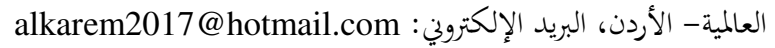

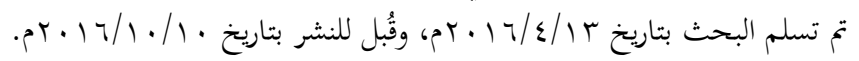




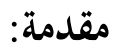

اهـتم ابن عاشور بعلم التفسير منـذ شبابه، وذلك عن طريق تـدبُّر القرآن الكريع،

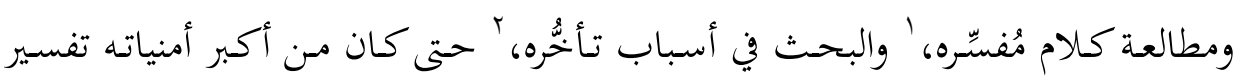

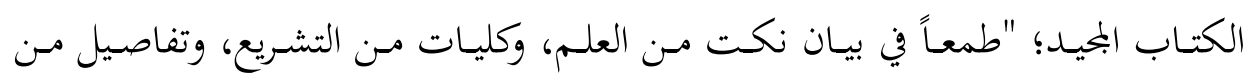

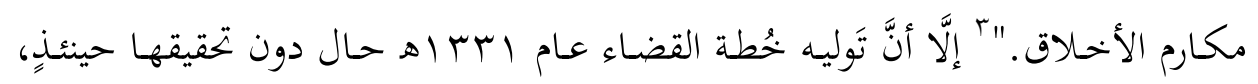

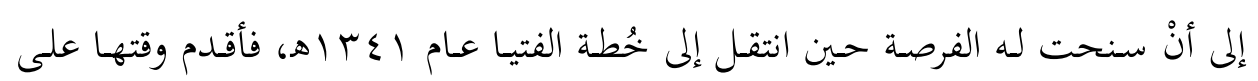

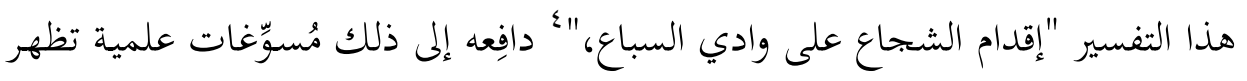
في أمرين اثنين:

الأول: أهمية علم التفسير عنده، التي تتجلَّى في المُبرِّرات التي ساقها لجعل التفسير

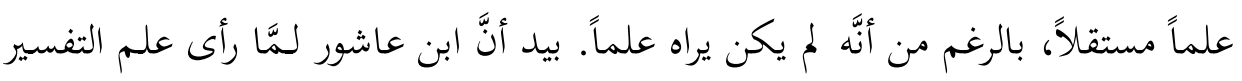

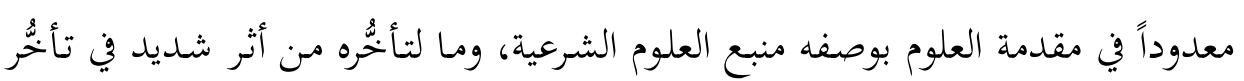

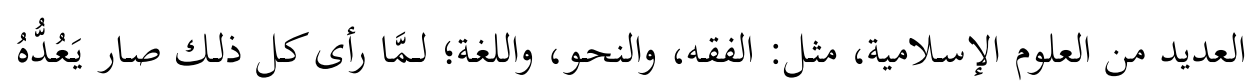

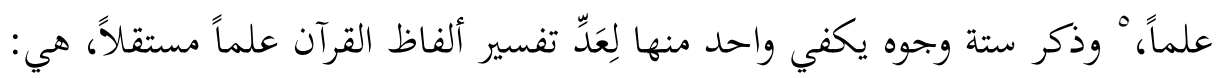
أ. مباحث علم التفسير تُفضي إلى استنباط علوم كثيرة، وقواعد كلية. ولا شك في

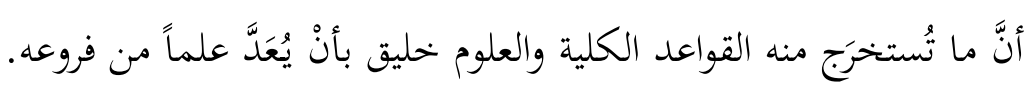

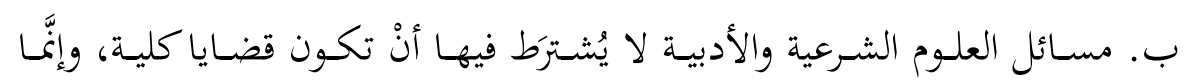
يكفي أنْ تفيد مباحثُها كمالاً علمياً لمُزاوِها.

' ابن عاشور، محمد الطاهر. تحرير المعنى السديد وتنوير العقل الجديد من تفسير الكتاب المجيد (التحرير

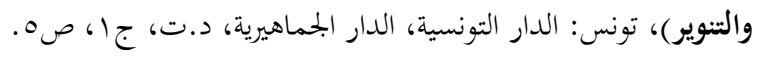

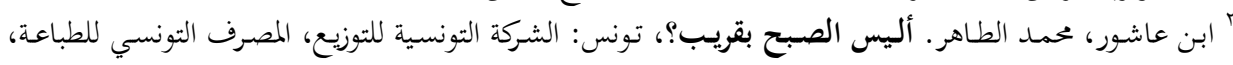

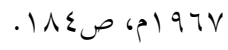

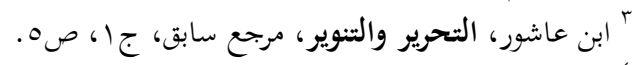

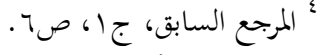

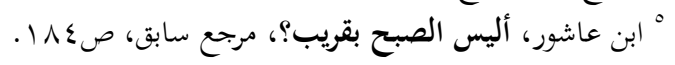




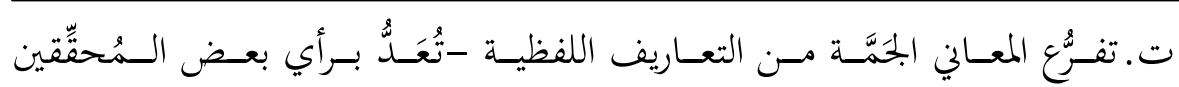
تصديقات- يُنزلها منزلة الكلية. ث. علم التفسير لا يخلو من قواعد كلية في أثنائه، فسُمّي بحموع ذلك علماً تغليباً.

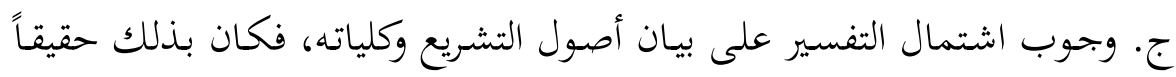
أنْ يُسمَّى علماً. ح. أول ما اشتغل به علماء الإسلام هو التفسير، ومُزاوله كان يكسب علوماً كليةً لها اختصاص بالقرآن المجيد.

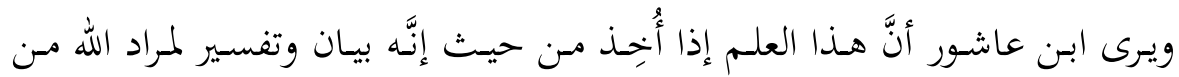

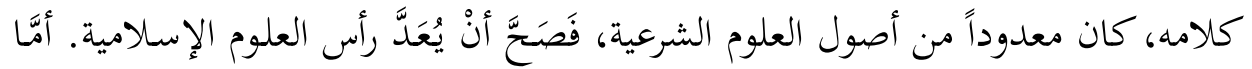

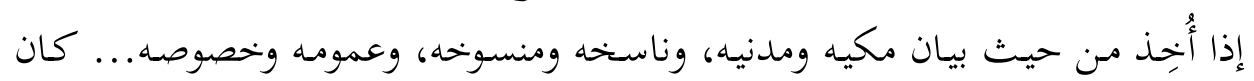

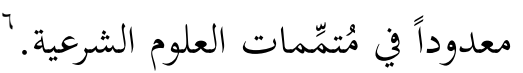
ويظهر لنـا من هذه الوجهوه الستة أنَّ ابن عاشور حَرَصَ على عـدم جعل التفسير

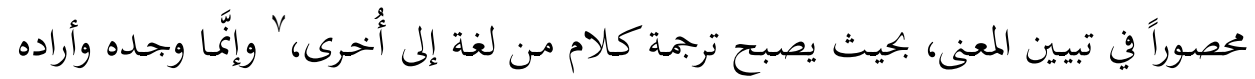

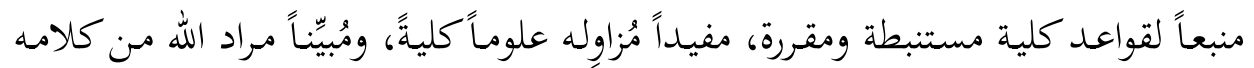

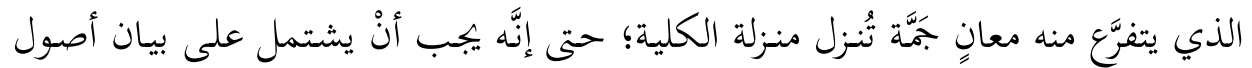
التشريع وكلياته.

ولا شـك في أنَّ هـذه الوجـوه قـد حظيـت باهتمـام ابـن عاشـور، بَلْدَه علـم التفسـير

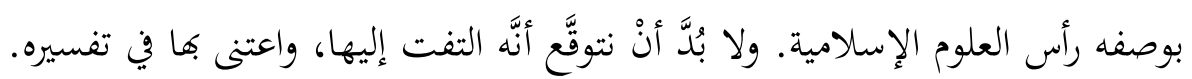
أمَّا الأمر الثاني الذي يُجلي المُسوِّغ العلمي لاهتمام ابن عاشور بالتفسير فهو إدراكه

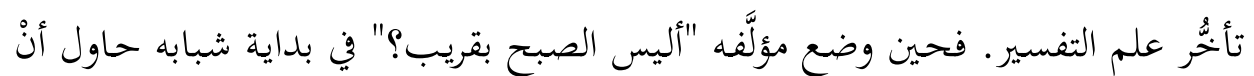

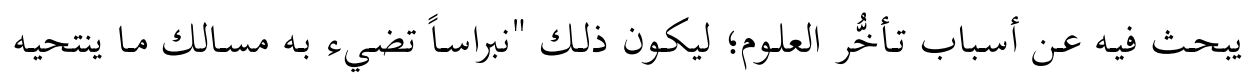


الأساتذة وما يهجرونه ممَّ يمهُّ بهم في أوقات المطالعة والتحرير، وليكون ذلك أيضاً تمهيداً

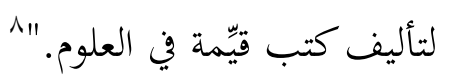

وقد بيَّن ابن عاشور في كتابه هذا أنَّ تفسير القرآن الكريم في العصور السابقة قد مرَّ

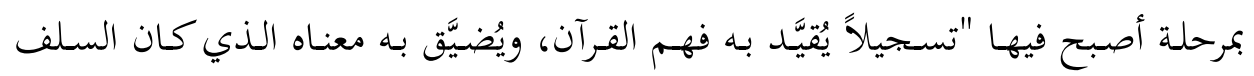
يقولون فيه: إنَّه لا تنقضي عجائبه، ولا تنفذ معانيه. "و ويعزو ابن عاشور هذا التضييق

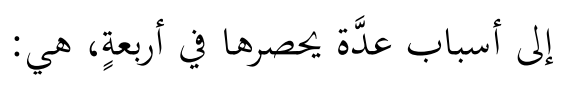

- الولع بالتوقيف والنقل؛ اتِّقاءً للغلط في القرآن، وزجراً للعامة عن التفسير من دون

$$
\text { أهلية حتى قالوا: "خطؤه كفر"، فتوهَّها الخاصة أصلاً. }
$$

- ضعف اللغة والبلاغة حتى وُجِدت تفاسير الباطنية والصوفية.

- الضعف في علوم ضـرورية لمعرفة عظمـة القـرآن العمرانيـة، مثل: التـاريخ، وفلسفة العمران، والأديان، والسياسة.

- الاستطراد في بعض التفاسير بذكر علوم متنوعة ضعيفة المناسبة في تفسير الآيات،

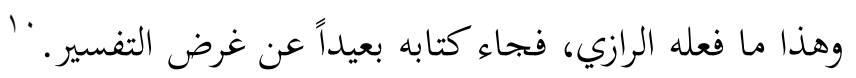

ولكن، إذاكان ابن عاشور -قبل تأليفه كتاب "التحرير والتنوير"- قد أدراك تأخُّر

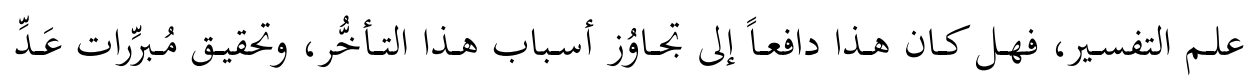
التفسير علماً عند تأليفه هذا الكتاب؟ فئ

أشـار ابن عاشور إلى الهدف مـن تأليفهـ هذا الكتاب في المقدمة، مُبيِناً أنَّهه يريد أنْ

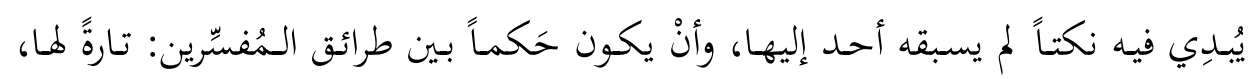

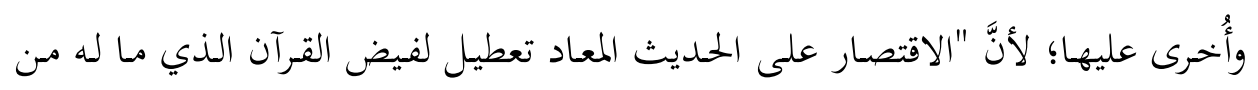


نفـاد." 'ا" فـاهتم في تفسـيره "بيـان وجـوه الإعجـاز، ونكـت البلاغـة العربيـة، وأسـاليب

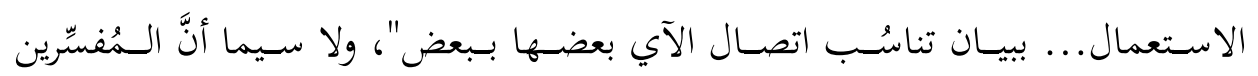

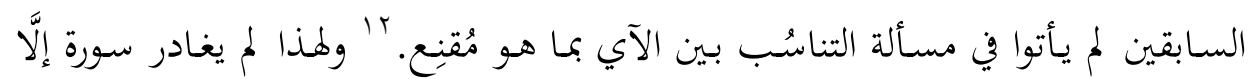
بَيَّن ما أحاط به من أغراضها؛ حتى لا يحجب الناظر عن روعة انسجامه، وروائع جماله. وقد عمل ابن عاشور أيضًا على تحقيق المفردات وضبطها ومعانيها مُّاّ خلَت منه الكثير من قواميس اللغة، وبذل جهده "في الكشف عن نكت من معاني القرآن وإعجازه خلَت

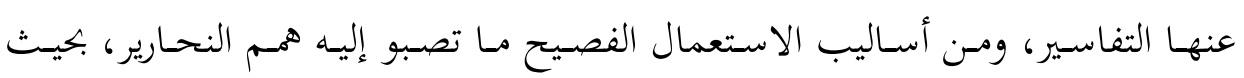
ساوى هذا التفسير على اختصاره مطولات القماطير، ففيه أحسن ما في التفاسير، وفيه

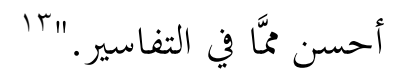

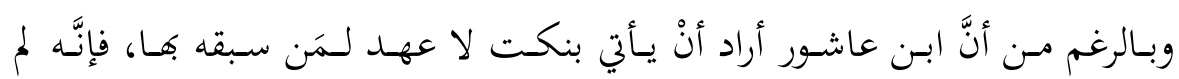
يهـدف إلى القطع مع التفاسير؛ فهو يعلم كثرةها، ويُدرِكِ -في الوقت نفسهـ- أنَّ غالبها

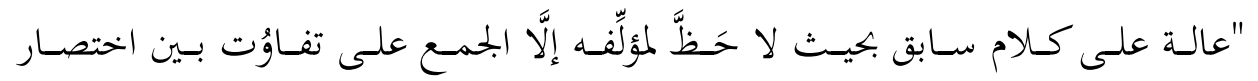

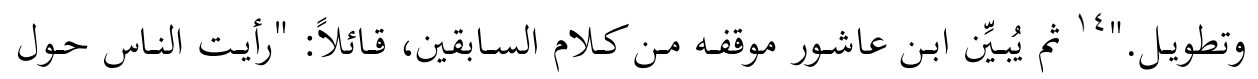
كمام الأقدمين أحسَ رَجُلين: رجل معتكف فيما شـاده الأقدمون، وآخر آخذذ بمعوله في

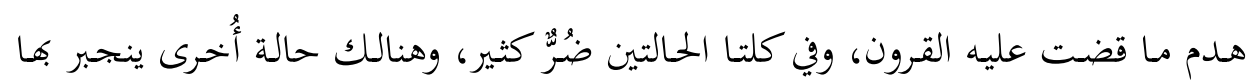

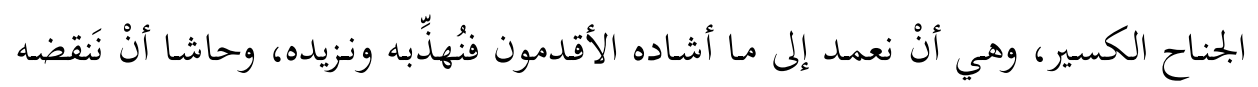

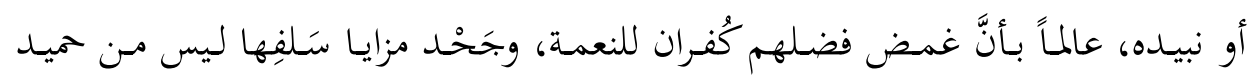
خصال الأمُّةَة. 1010

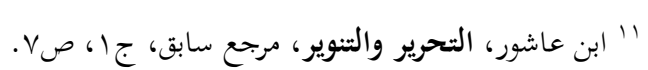

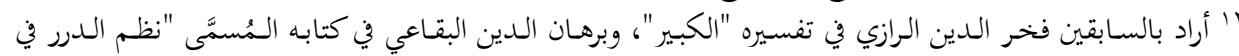

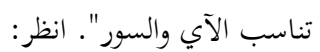

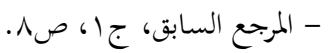

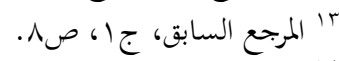

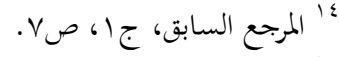

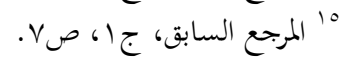




\section{أولاً: مرتكزات إصلاح التفسير في "التحرير والتنوير"}

كان ابن عاشور مُدرِاًا وجود كسنر أصاب علم التفسير في العصور السابقة، وأنَّهَ ينبغي بتجبيه؛ لكي يكون فاعلاً في العصور التالية.

وقد سعى ابن عاشور في تفسيره إلى بتجبير الكسنر الذي أصاب علم التفسير، بأنْ

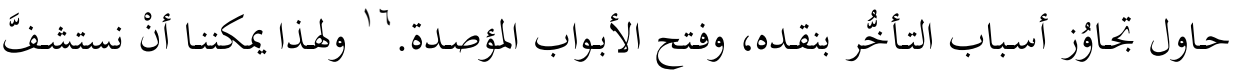

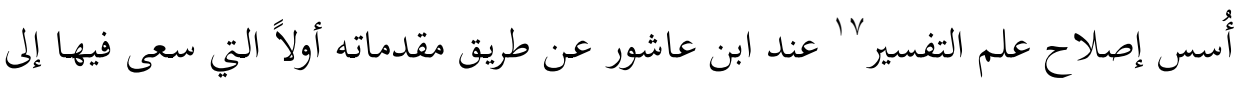

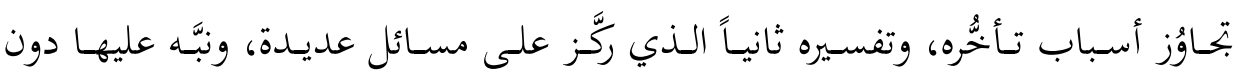

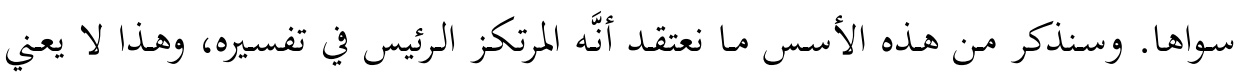

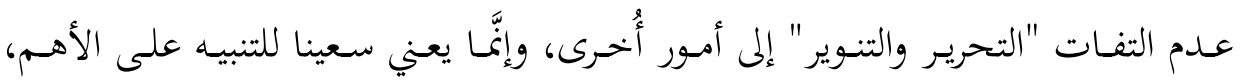

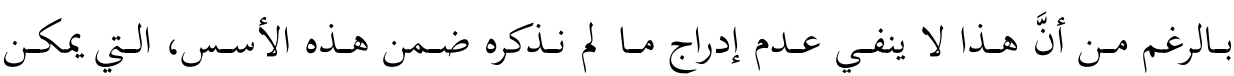

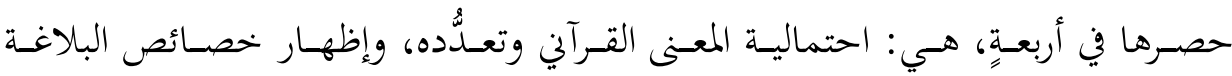

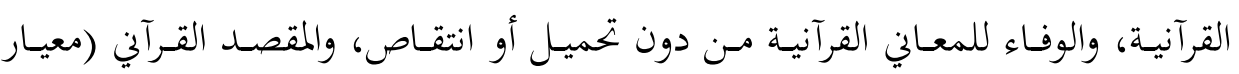
التفسير وغايته).

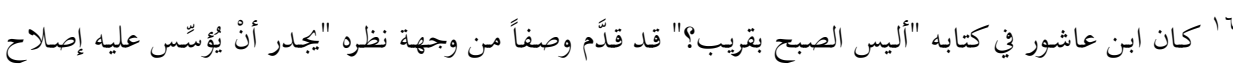

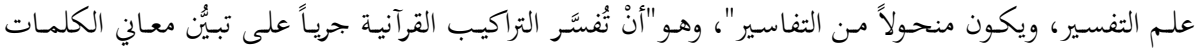

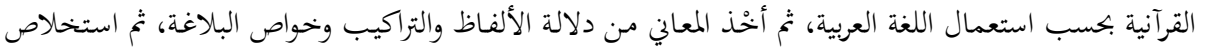

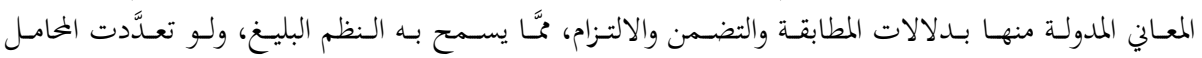

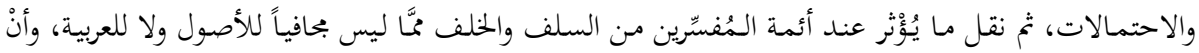

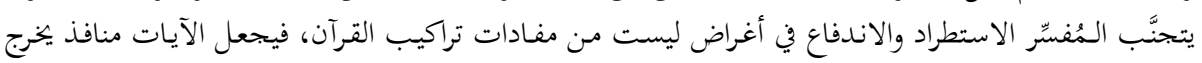

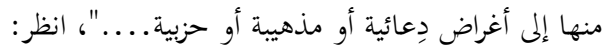

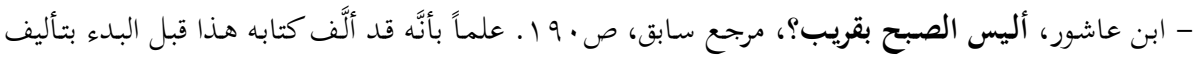

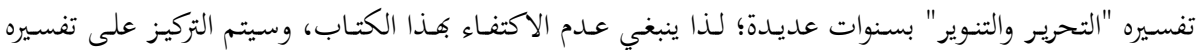
لاستجاء أسس إصلاح علم التفسير عنده.

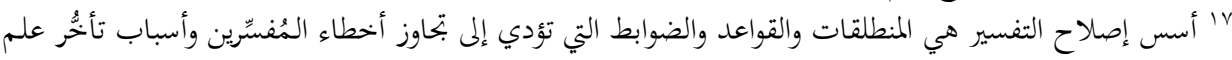
التفسير لبناء تفسير يكشف عن مراد الله -عزَّوجلَّلَ- في كتابه. 


\section{ا ـ احتمالية المعنى القرآني وتعدُّده:}

اختار ابن عاشور لمقدمة تفسيره الثالثة عنوان "في صحة التفسير بغير المأثور ومعنى

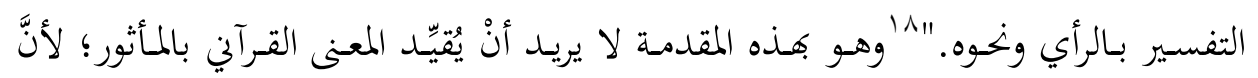

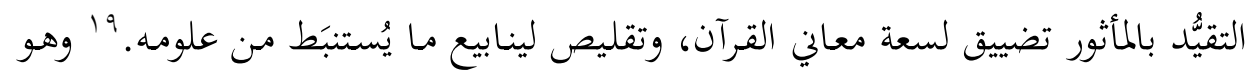

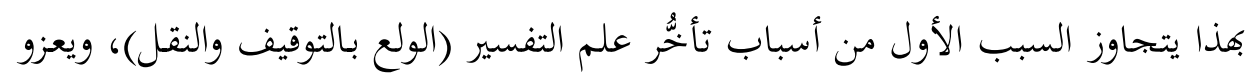

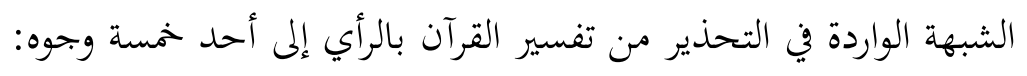
أ. "المراد بـالرأي هـو القول عن بحـرد خـاطر دون استناد إلى نظر في أدلة العربية

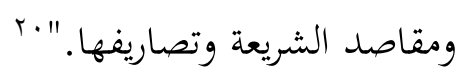
ب. التفسير من دون الإحاطة بجوانب الآية ومواد التفسير.

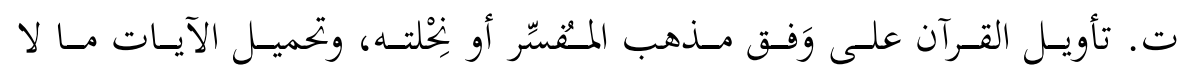

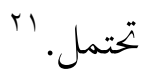
ث. تضييق المعنى القرآني استناداً إلى ما يقتضيه اللفظ، مع الزعم أنَّه هو المراد دون غيره. ج. "أنْ يكون القصد من التحذير أنْذذ الحيطة في التدبُّر والتأويل، ونبذ التسرُّع إلى

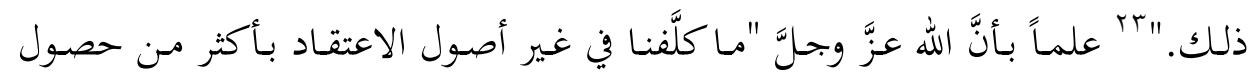

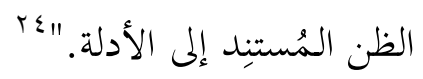

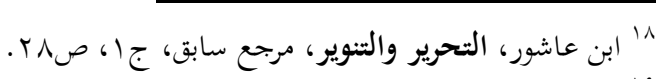

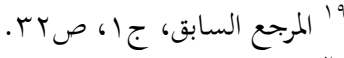

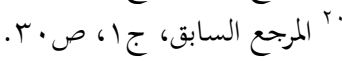

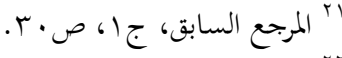

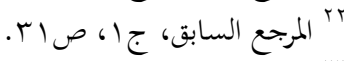

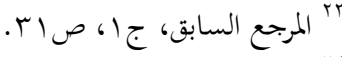

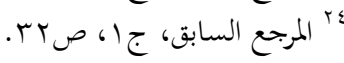


وتأسيساً على ما سبق، فقد أباح ابن عاشور لـمَن استجمع العلوم التي يستمد منها

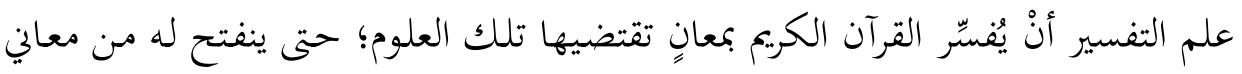

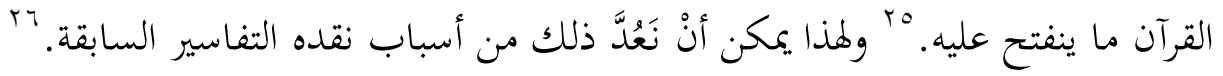
ولكن، إذا كان عدم تقيُّد المعنى بالمأثنور عند ابن عاشور لr يُعَدُّ خطوةً مهمةً للتفسير

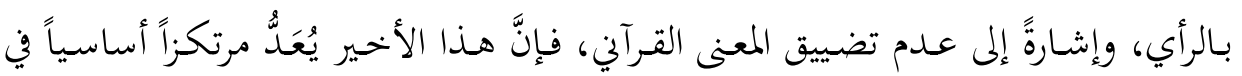

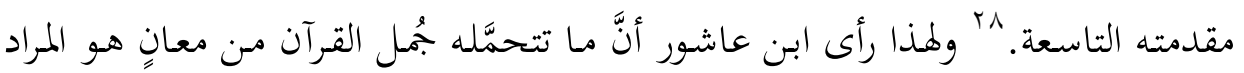

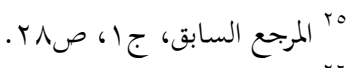

$$
\begin{aligned}
& \text { : }
\end{aligned}
$$

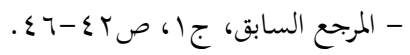

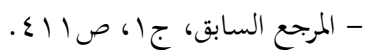

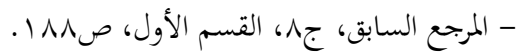

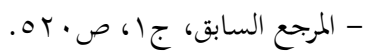

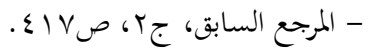

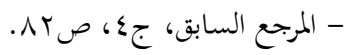

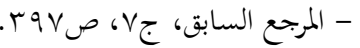

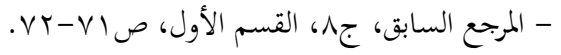

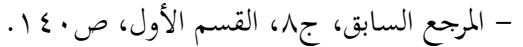

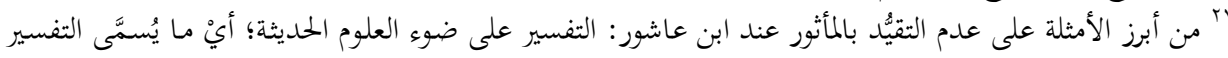

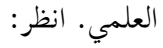

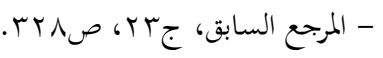

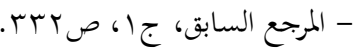

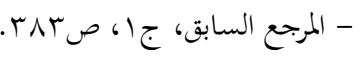

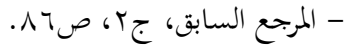

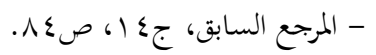

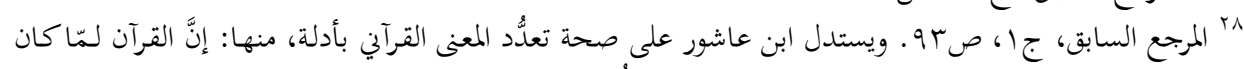

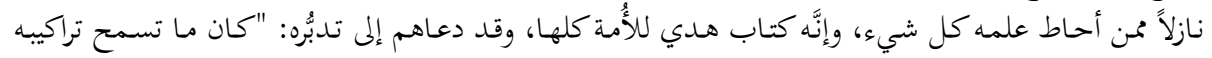

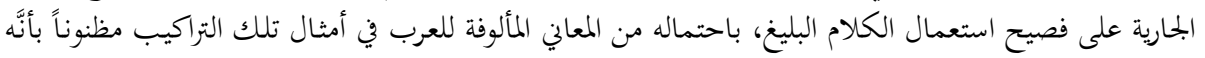

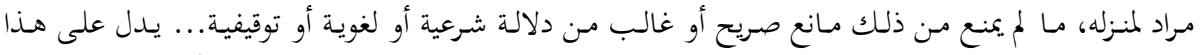

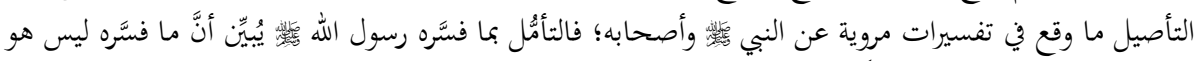

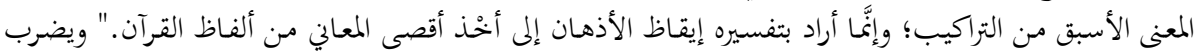

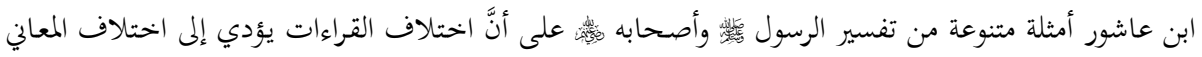

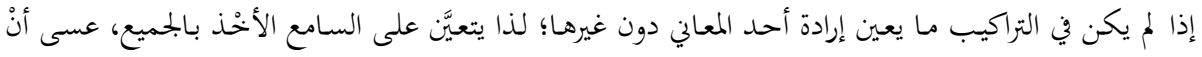


والمبتغى طالما سمحت بذلك "كلمات القرآن وتراكيبه وإعرابه ودلالته؛ من اشتراك وحقيقة

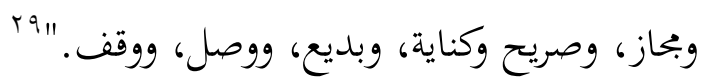

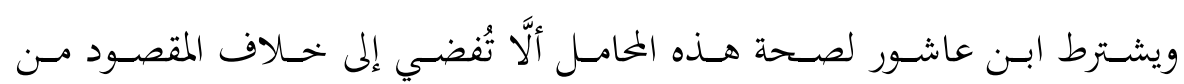

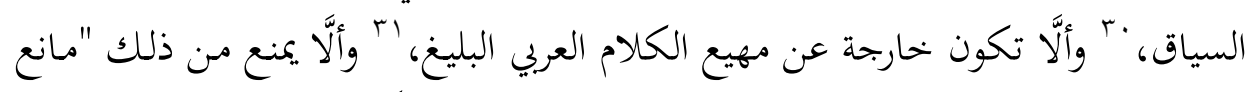

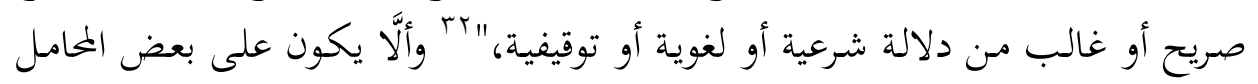

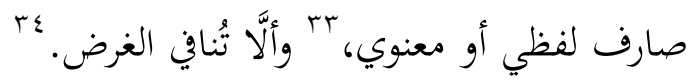
وفيما يأتي إجمالٌ لما سعى ابن عاشور إلى تحقيقه من القول باحتمالية المعنى وتعدُّده:

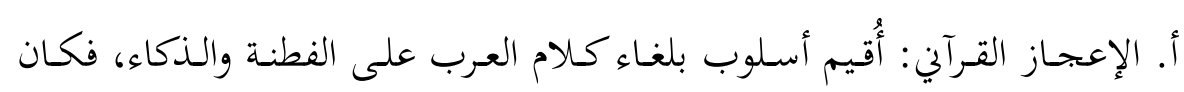

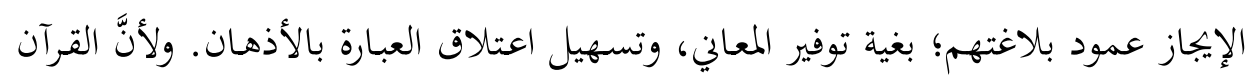

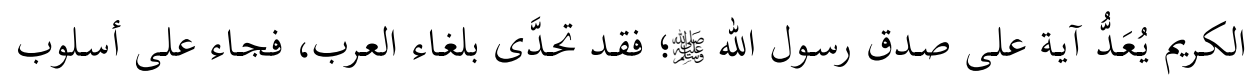

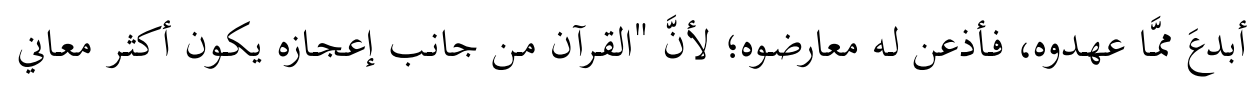

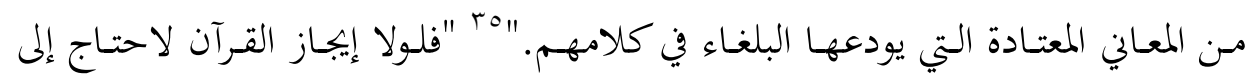

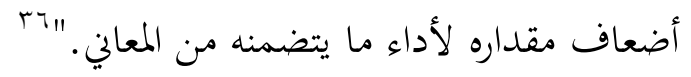

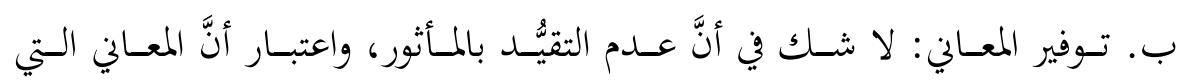

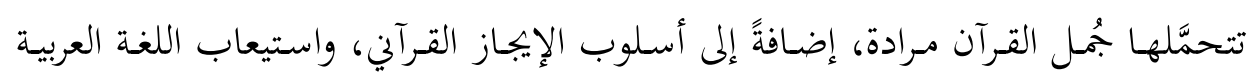

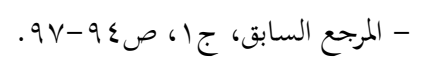

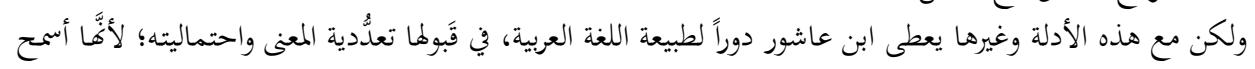

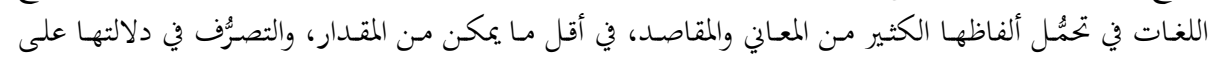

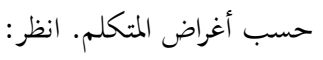

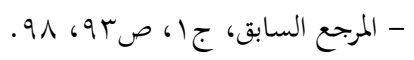

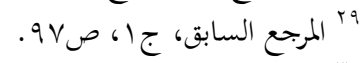

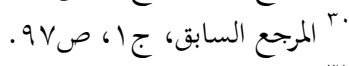

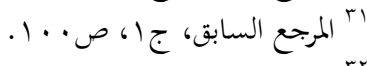

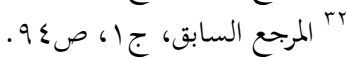

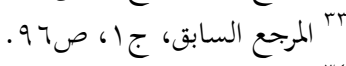

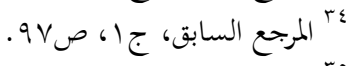

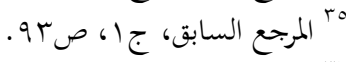

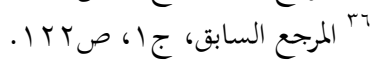




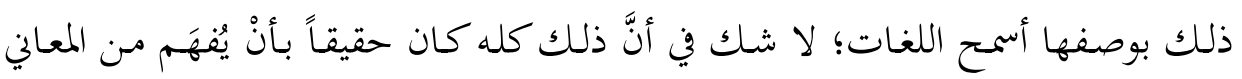

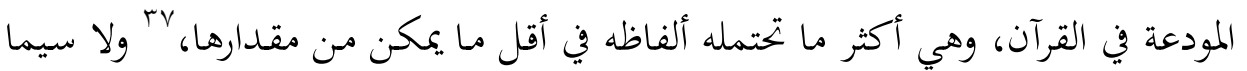

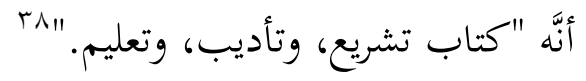

ت. تحقيق المقاصد القرآنية وتحصيلها: إنَّ توفير المعاني القرآنية ماكان إلَّا "ليحصل

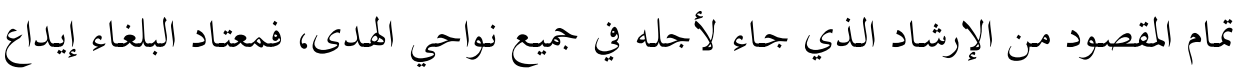

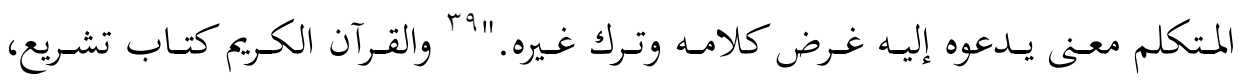
وتأديب، وتعليم. •

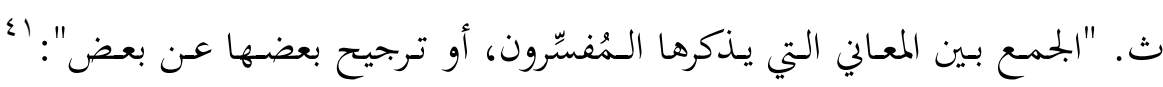

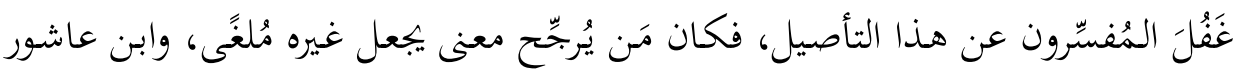

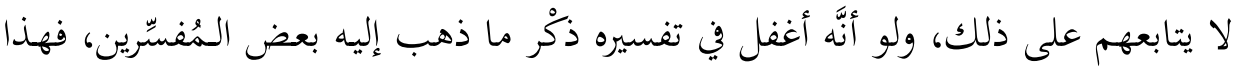

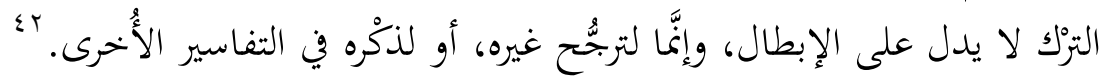

\section{r. إظهار خصائص البلاغة القرآنية:}

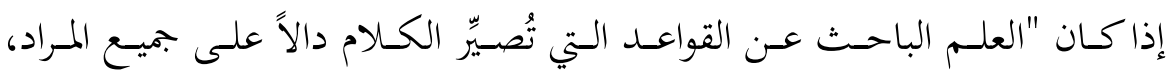

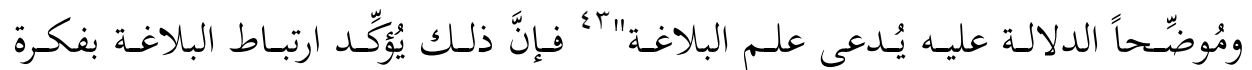

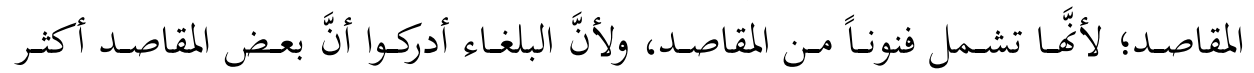

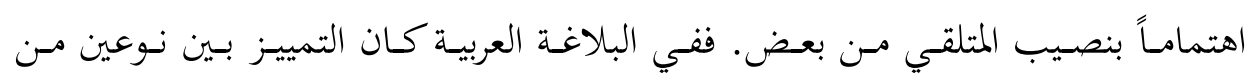

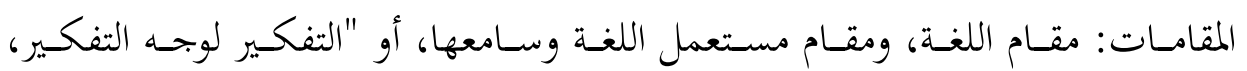

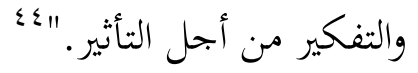

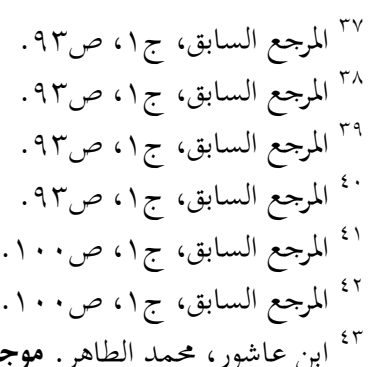

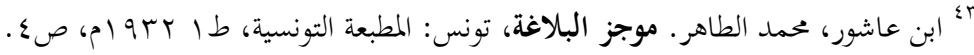

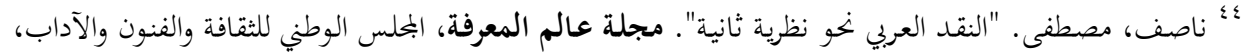

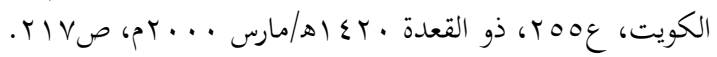


وابن عاشور كان حريصاً في تفسيره على بيان النواحي البلاغية؛ لأغَّا تُحُقِّق مقصداً

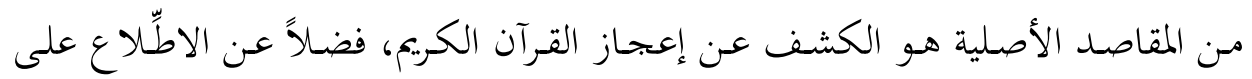

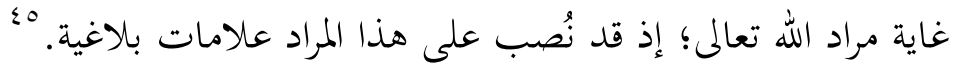

وبناءً على السبب الأخير لهذا الحرص، فقد يتبادر إلى الذهن السؤال الآتي عن دور

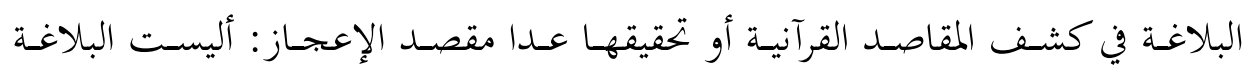

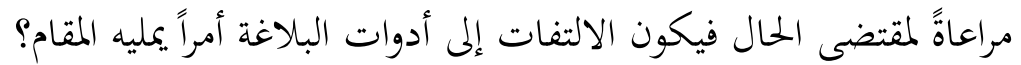
وقـد اشترط ابن عاشور في مقدمته الثانية استمداد علمم التفسير "للمفسّر العربي

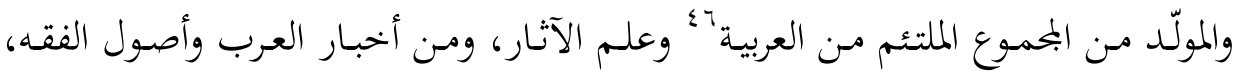

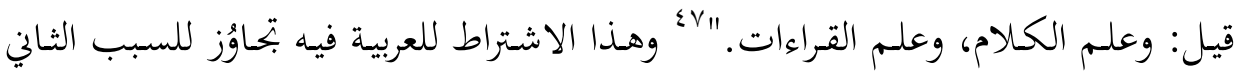

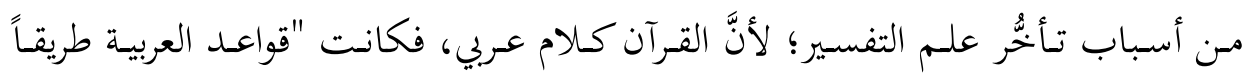

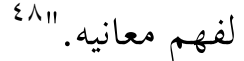

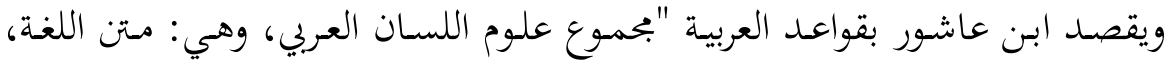

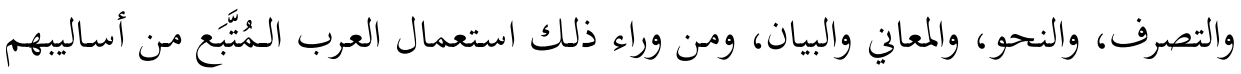

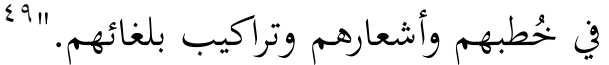

وقد صرَّح ابن عاشور في تمهيد تفسيره أنَّه يلتزم فيه بعدم إغفال التنبيه على ما يلوح

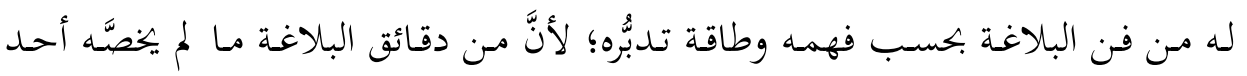

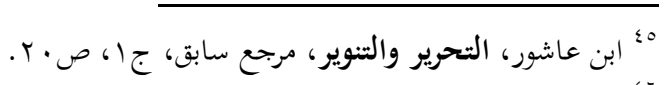

- الداسي. صالح. "منهج الإمام محمد الطاهر ابن عاشور من خحلال التحرير والتنوير". مجلة الهداية،، عددج، س

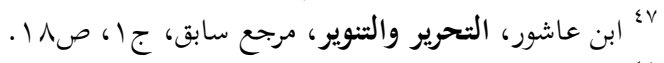

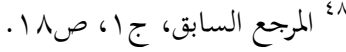

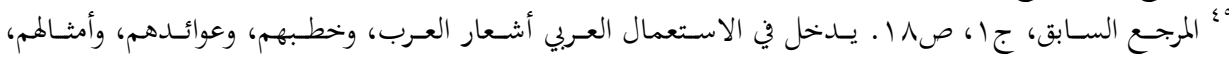

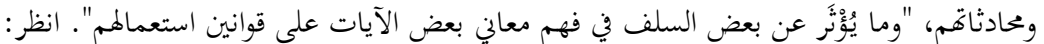

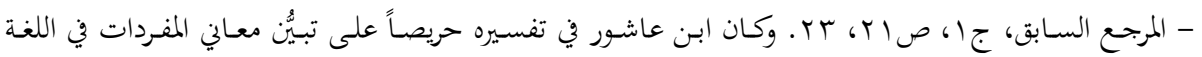

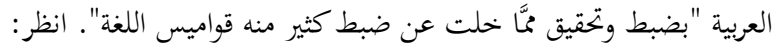

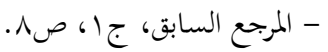




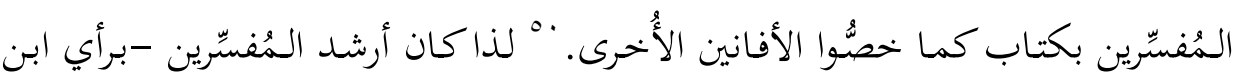
عاشور- إلى تحقيق "الغرض من التفسير الذين جعلوا تفاسيرهم مـن جهة البلاغة، ولعل

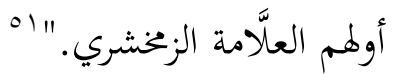

إذن، فقد التزم ابن عاشور في تفسيره ببيان الدقائق البلاغية؛ لأفَّا تُحِّق الغرض من

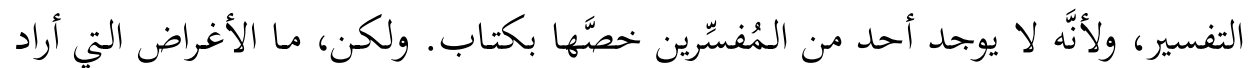

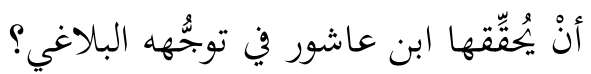

ويُقِرِّر ابن عاشور أنَّ "لعلمي البيان والمعاني مزيد اختصاص بعلم التفسير"؛ "لأفَّما وسيلة لإظهار خصائص البالاغة القرآنية، وما تشتمل عليه الآيات مـ تفاصيل المعاني

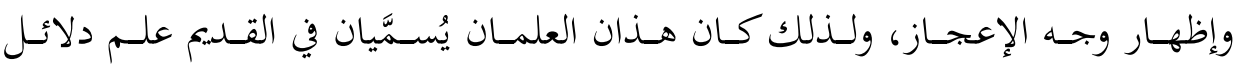

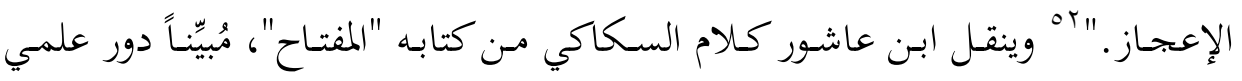
البيان والمعاني في تفسير القرآن الكريم: "وفيما ذكرنا ما يُنبِّه على أنَّ الواقف على على تمام مراد

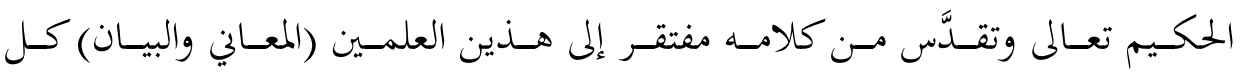

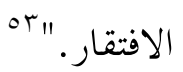

ويُعلِّق ابن عاشور على قول السكاكي "تمام مراد الحكيم" بقوله: "أي المقصود هو

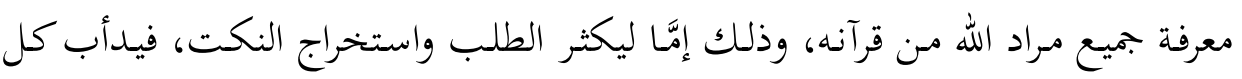

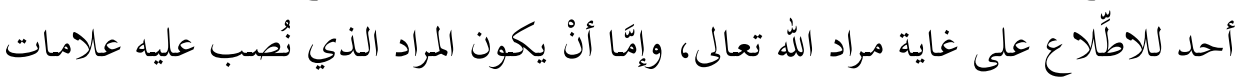
بلاغية وهو منحصر فيما يقتضيه المقام بحسب التبُّع، والكل مظنة عدم التناهي وباعث

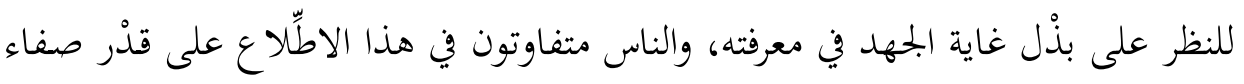

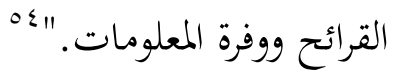

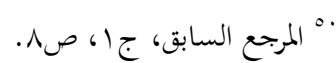

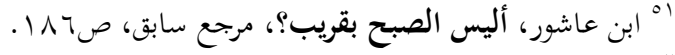

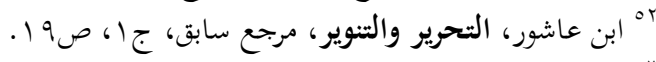

- السكاكي، أبو يعقوب يوسف بن أبي بكر. مفتاح العلوم. مصر : مطبعة التقدم العلمية، د.ت، ص ص. ل.

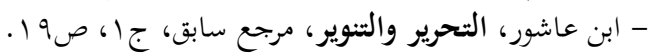

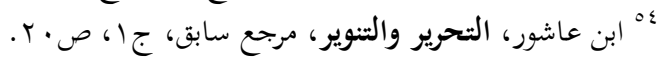


متَّا تقدَّم يمكن إجمال دور البلاغة في التفسير عند ابن عاشور فيما يأتي: أ. وسيلة لإظهار خصائص البلاغة القرآنية.

ب. بيان ما تشتمل عليه الآيات من تفاصيل المعاني، والوقوف على مقاصدها وتمام

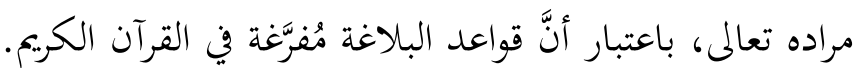
ت. الحـث على النظر وبذْل الجهاد في الوصول إلى غاية مراد الله تعالى؛ إمَّا لإكثار

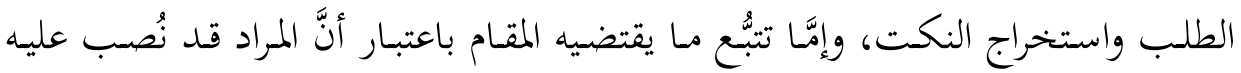
علامات بلاغية، والكل مظنة عدم التناهي المُفضي إلى الأُسِّ الأول (توفير المعاني). ث. إظهار الإعجاز القرآني. "فالمُفسِّر بحاجة إلى بيان ما في آي القرآن من طرق

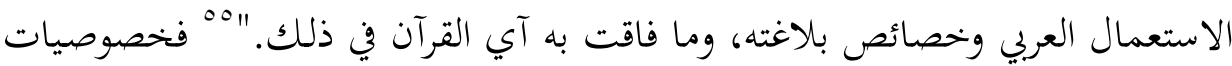

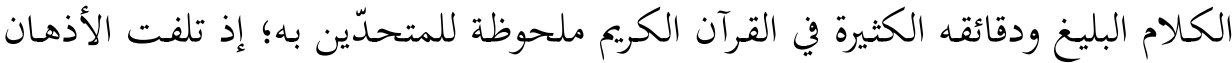

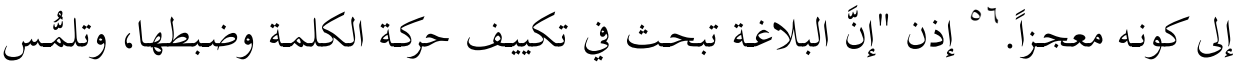

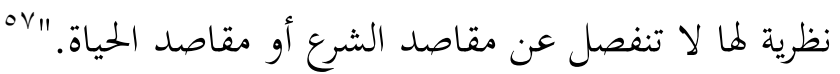
وهذا مـا سعى إليه ابن عاشور في توجُههه البلاغي مـن خهالال تطبيقاته التفسيرية؛

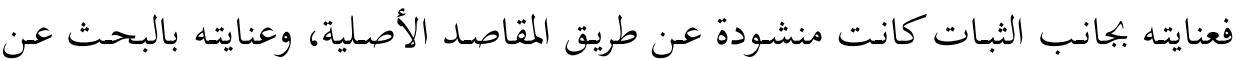

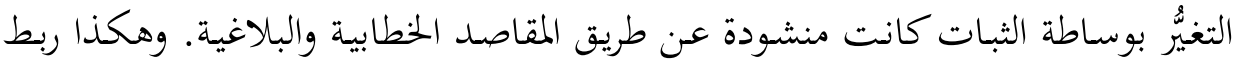

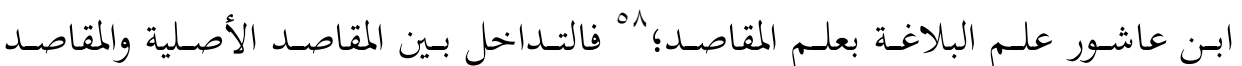

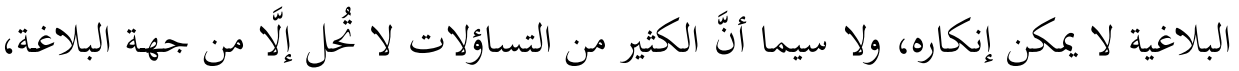
مثل: تعليل التشابه والاختلاف في بعض الآيات الحاملة المعنى نفسه أو اللفظ عينه.

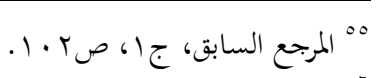

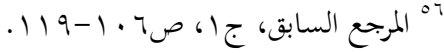

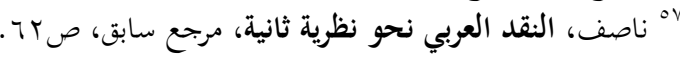

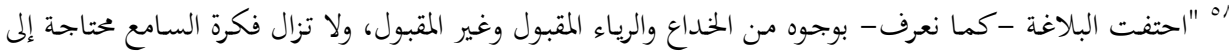

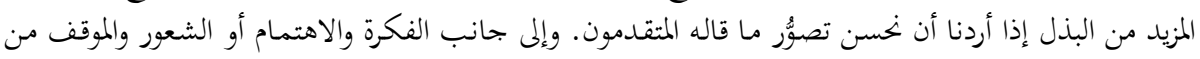

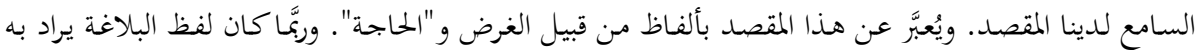

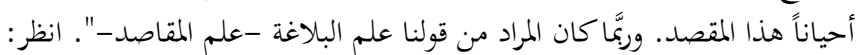

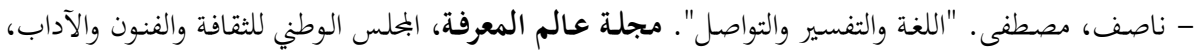

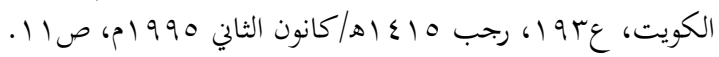


ولمَّا كانت كل آية من آيات القرآن الكريم لا تخلو من إحدى دقائق البلاغة، فقد التزم ابن عاشور بتجلية هذه الدقائق إذا لاحت له في أيِّ آية حسب مَبْلغ فهمهه وطاقة

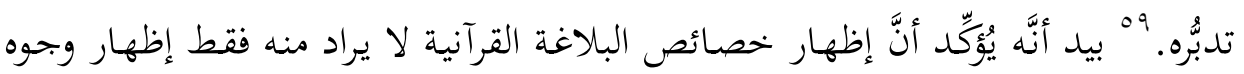

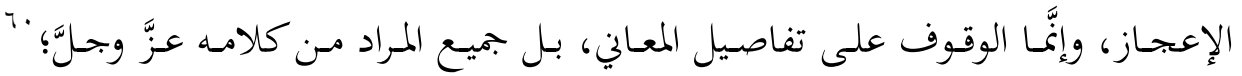
"وذلك إمَّا ليكثر الطلب واستخراج النكت، فيدأب كل أحد للاطِّلاع على غاية مراد

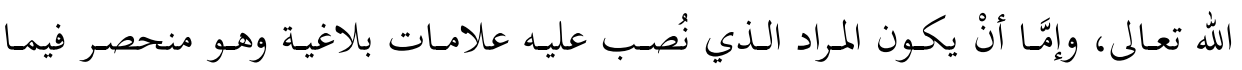

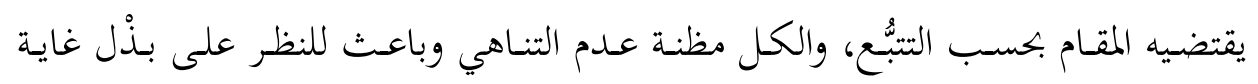

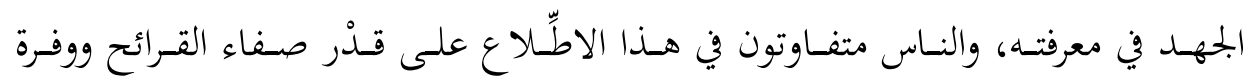
المعلومات.

ويريد ابن عاشور من الاحتمال الثاني أنَّ ثمَّة علامات بلات بلاغية منحصرة فيما يقتضيه

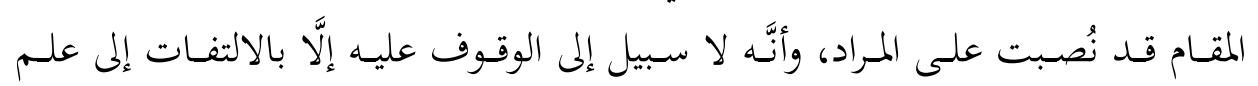

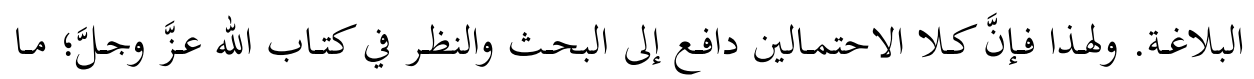
يجعل المُتأمّل في "التحرير والتنوير" يَلحظ كثافة التعليلات البلاغية بكل أنواعها؛ مـن:

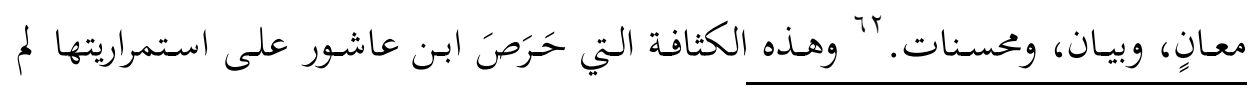

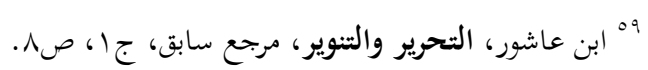

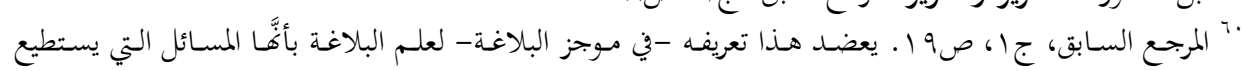

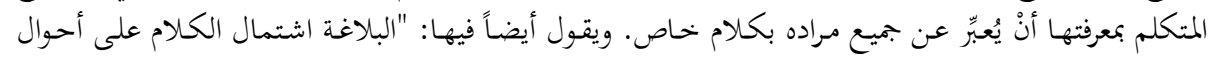

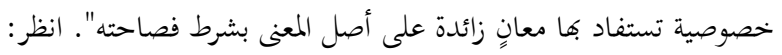

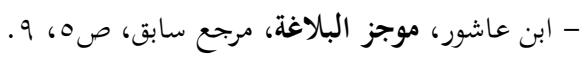

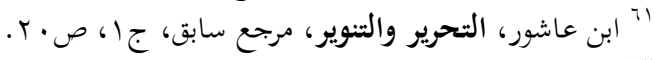

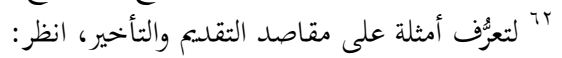

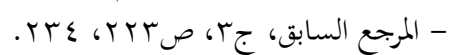

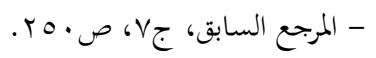

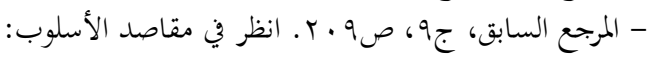

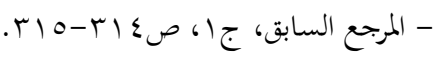
- المرجع السابق، جل، صم الـ ـانظر في التشبيه والاستعارة:

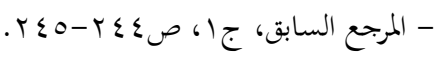

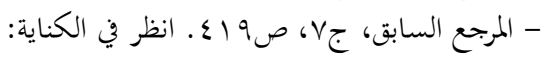

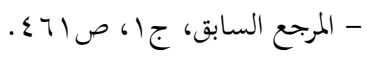

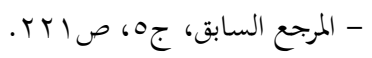




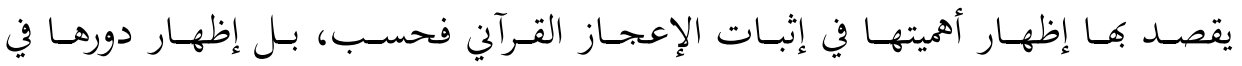

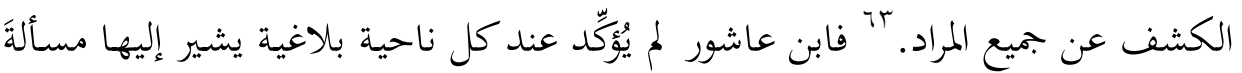

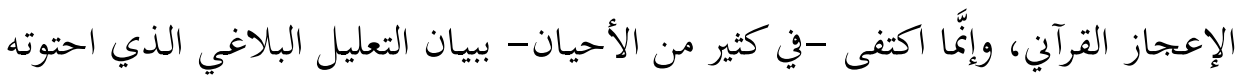

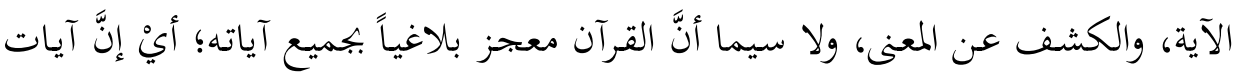
القرآن دالة على الإعجاز، وعلى مقاصد أُخرى.

ومن الأمثلة التي بُحلّي البُعْد التعليلي للاستعمال البلاغي في القرآن الكريم قوله

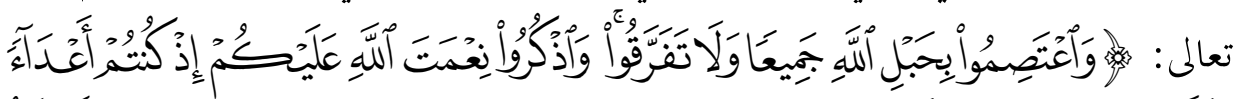

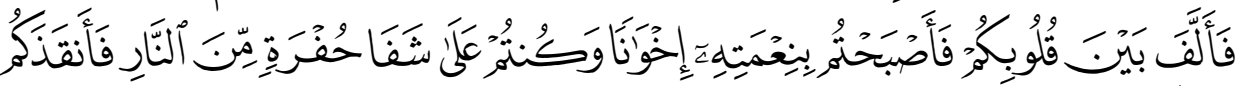

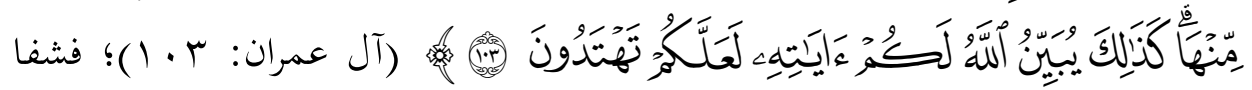

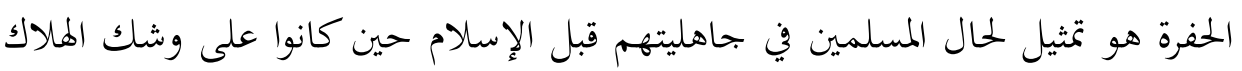

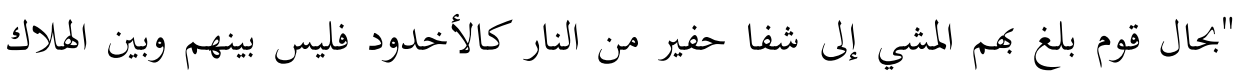

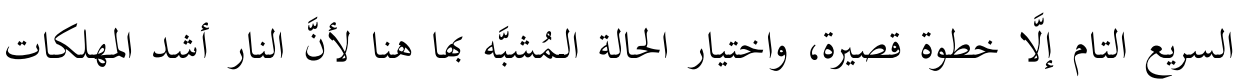
إهلاكاً، وأسرعها، وهذا هو المناسب في حمل الآية ليكون الامتنان بنعمتين محسوستين

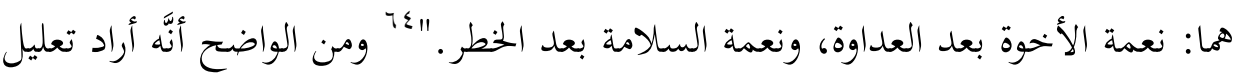
الاختيار القرآني للحالة المشبَّه بها، والتركيز على بيان مناسبة التمثيل لمقصد الآية.

\footnotetext{
- المرجع السابق، جV، صזr. انظر في الإيجاز:

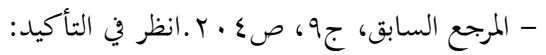

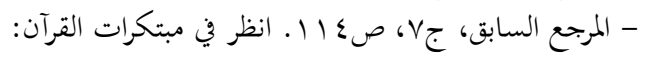

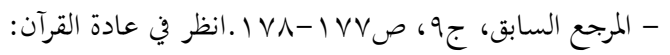

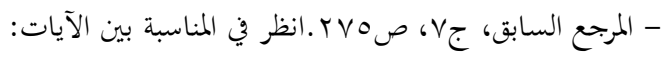

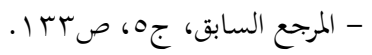

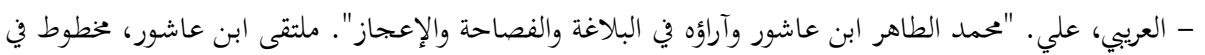

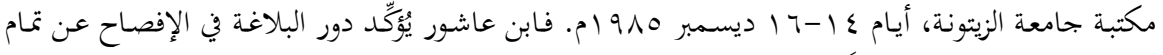

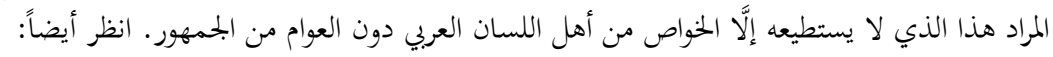

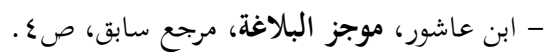

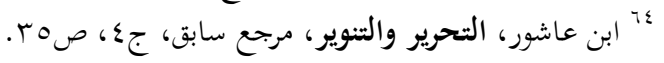


ومن الأمثلة أيضاً بيان ابن عاشور غرض العدول عن مقتضى الظاهر في قوله تعالى:

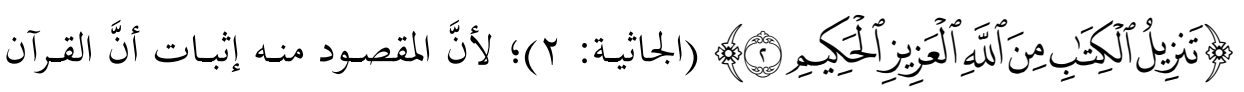

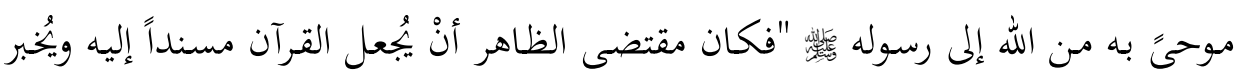

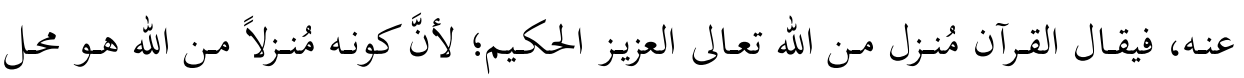

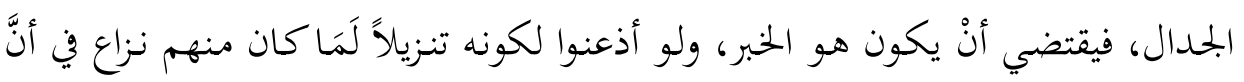
تنزيله من الله، ولكن خولف مُقتضى الظاهر لغرضين: أحدهما: التشويق إلى تلقي الخبر؛

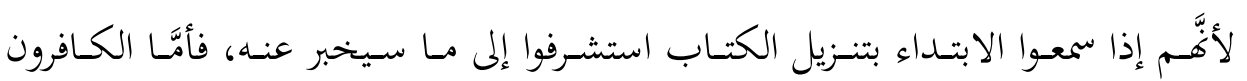

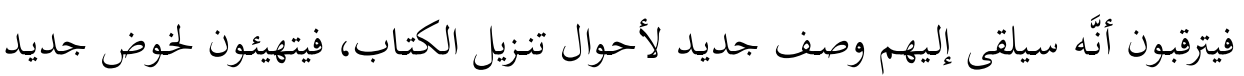

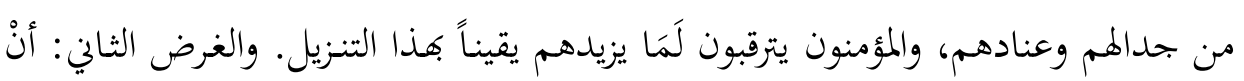

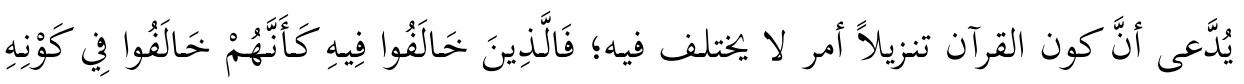

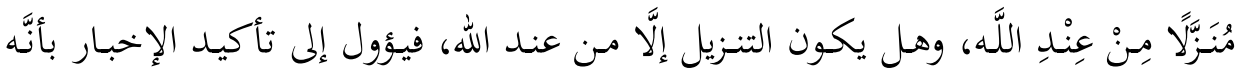

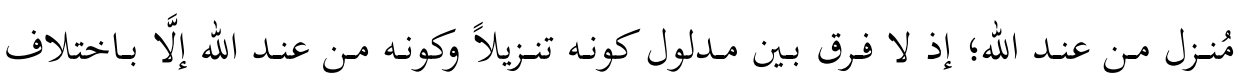

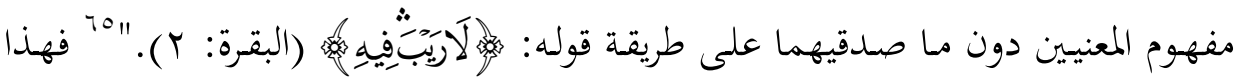

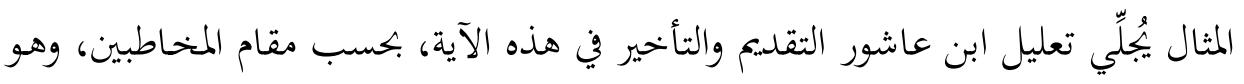

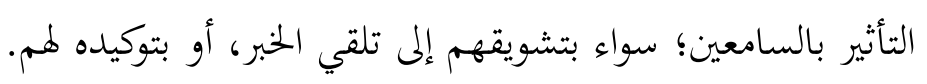

\section{r. الوفاء للمعاني القرآنية من دون تحميل أو انتقاص:}

ميَّز ابن عاشور بين مَن "يُعسِّر القرآن بما يخرج عن الأغراض المرادة منه، وبين من وقن

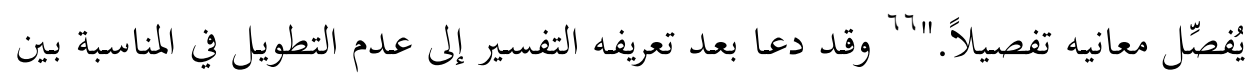

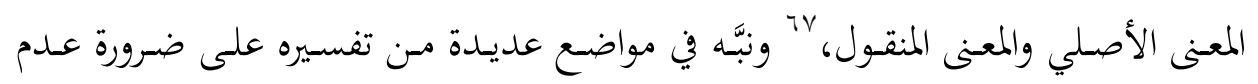

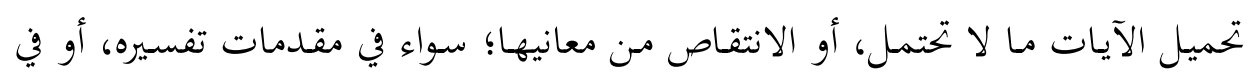

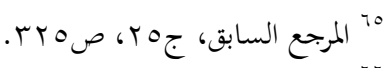

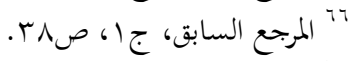

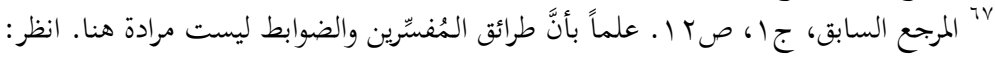

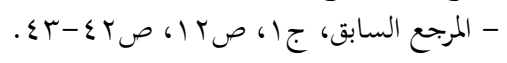




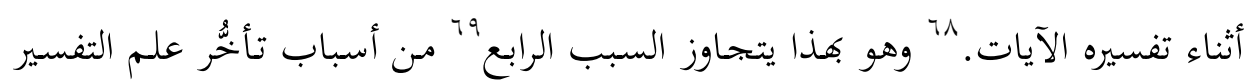
المُتمثّل في الاستطراد إلى علوم متنوعة ضعيفة المناسبة لموضوع تفسير الآية القرآنية، مثل:

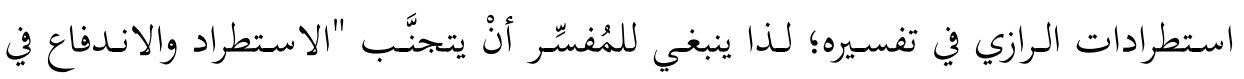

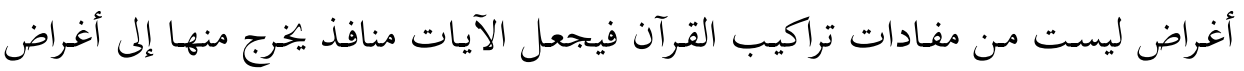

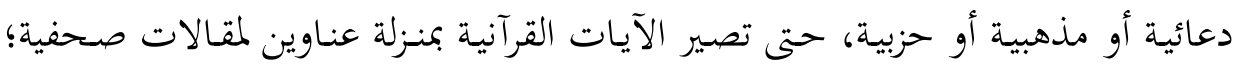

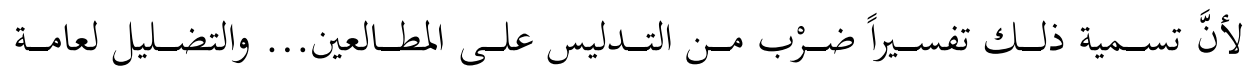

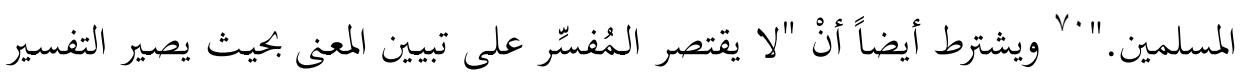

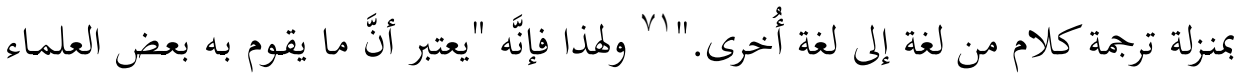

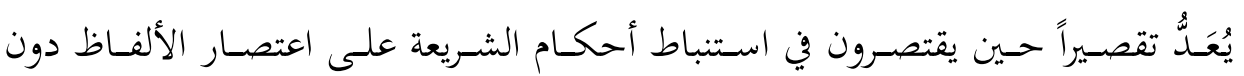

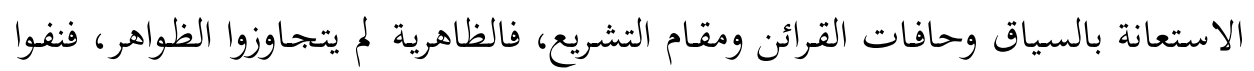

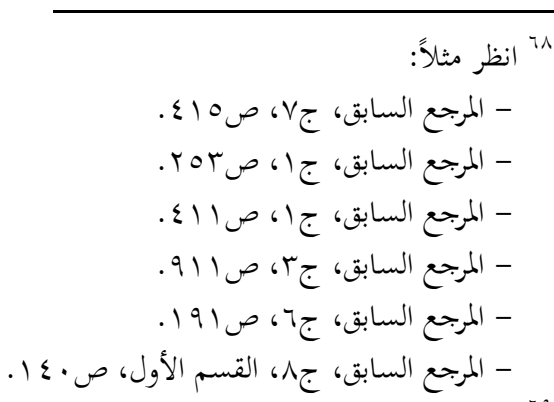

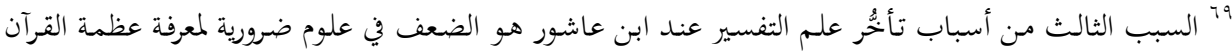

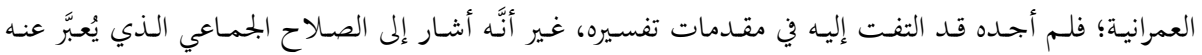

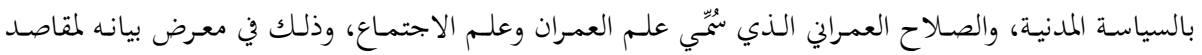

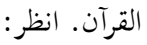
- المرجع السابق، جا، صملم. وبيَّن أيضاً علاقة العلوم بالقرآن، وجعلها على أربع مراتب. انظر :

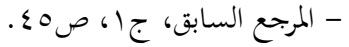

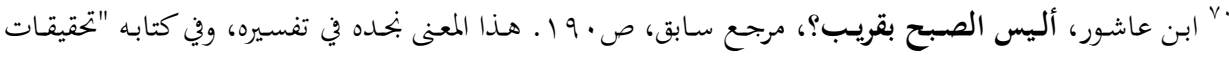

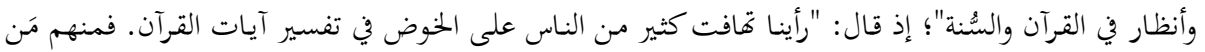

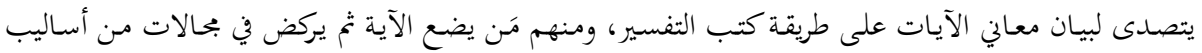

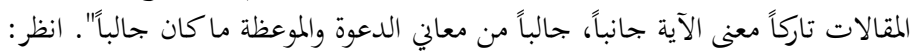

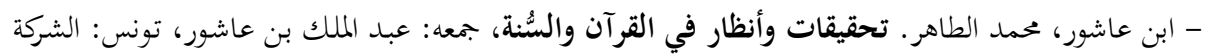

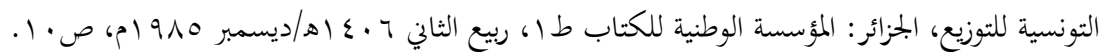

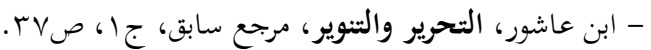

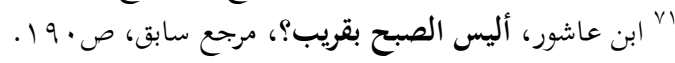




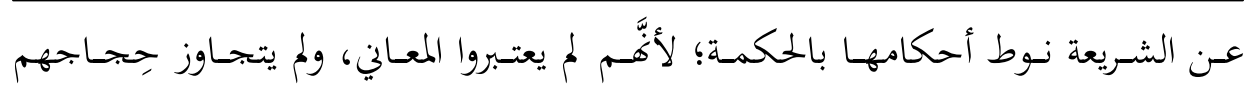

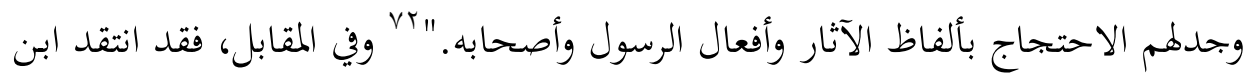

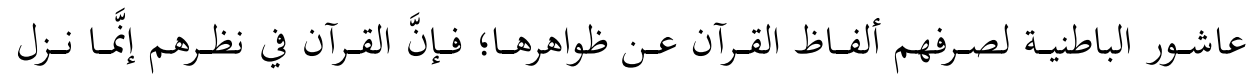

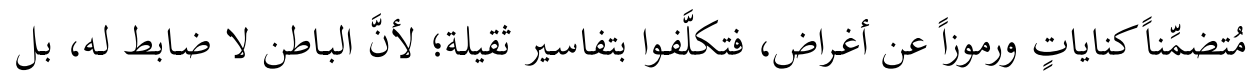

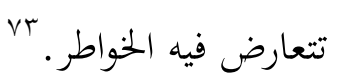

ويبرز حرص ابن عاشور على الوفاء للمعنى مسن دون زيادة أو نقصـان، في الوجـوه

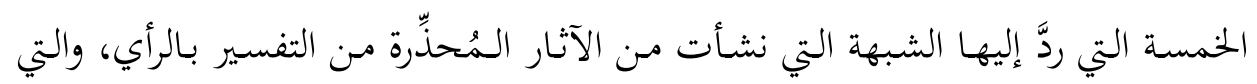
حَرَصَ فيها على جعل التفسير المـدموم هـو التفسير الذي يتم فيه تحميل الآيات مـا لا تحتمل، أو انتقاص معانيها.

ولا شـك في أنَّ أيَّ تفسير لـن ينـال القبـول إذا لمُ يكـن مـراده الوصسول إلى المقاصد

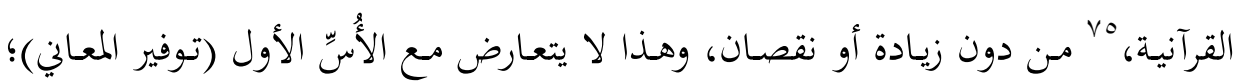
لأنَّ تحقُقْه وتحقيقه عند ابن عاشور يكون ضمن شروط، هي في غايتها تسعى إلى عدم

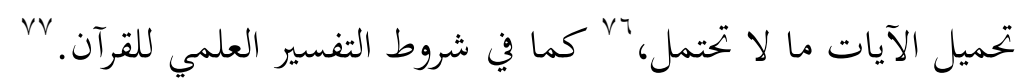

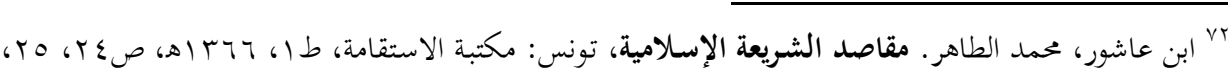

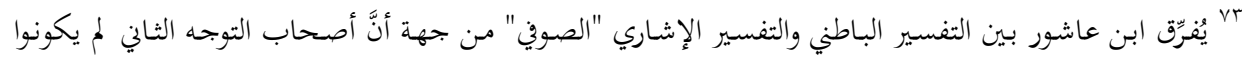

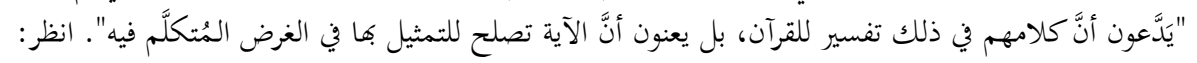

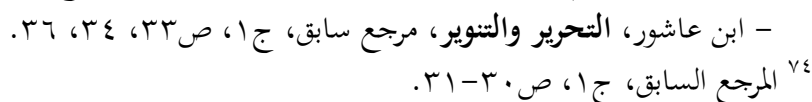

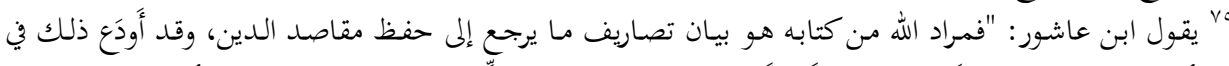

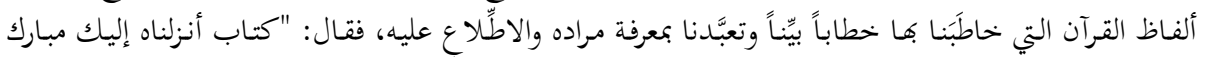

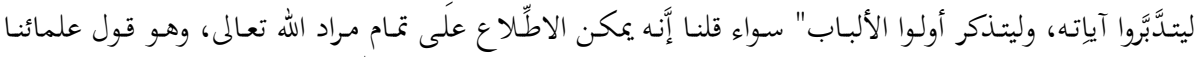

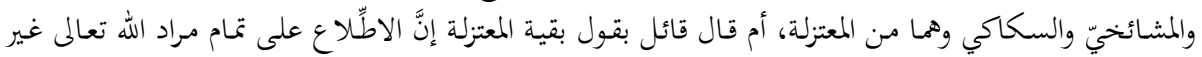

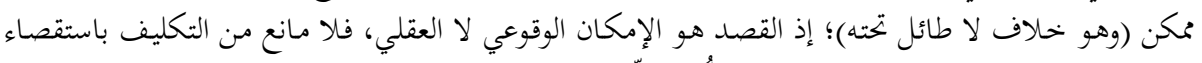

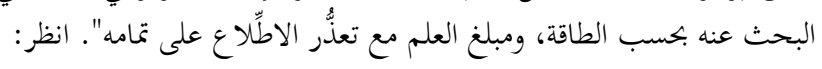

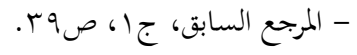

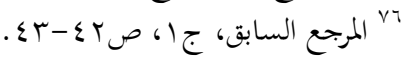




\section{ع. المقصد القرآني (معيار التفسير وغايته):}

جعـل ابـن عاشـور عنـوان مقدمتـه الرابعـة "فيمـا يهـق أنْ يكـون غـرض الـمُفسِّر

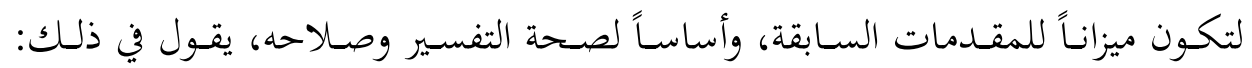

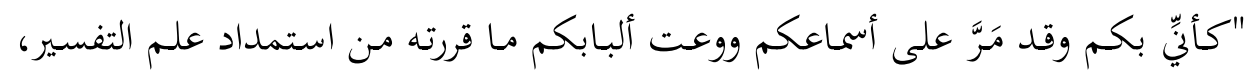

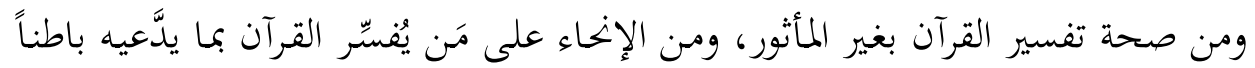
ينافي مقصود القرآن، ومسن التفرقة بين ذلك وبين الإشـارات، تتطلعون بعدُ إلى الإفصاح عن غاية المُفسِّر من التفسير، وعن معرفة المقاصد التي نزل القرآن لبياها حتى تستبين

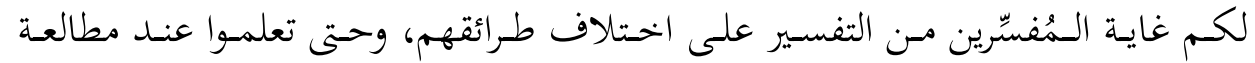

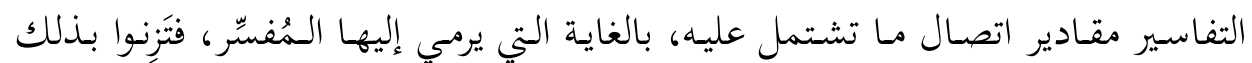

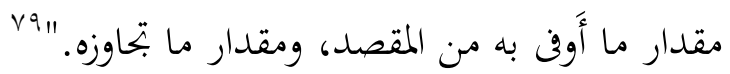

لقد أراد ابن عاشور مـن هذه المقدمـة بيان أمرين؛ الأول: مـا ينبغي أنْ تكون غاية المُفسِّر من تفسيره، والثاني: معرفة المقاصد التي نزل القرآن لبياها. ويهدف ابن عاشور من بيان هذين الأمرين إلى معرفة مدى إيفاء المُفسِّر للمقاصد

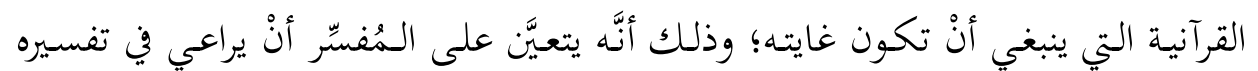

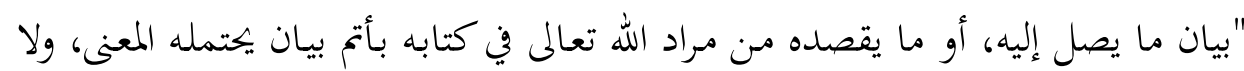

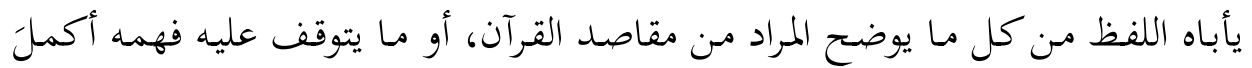

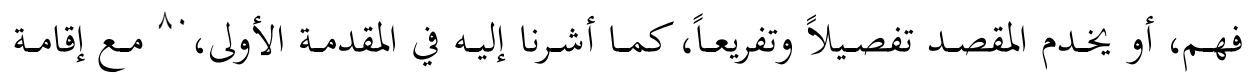

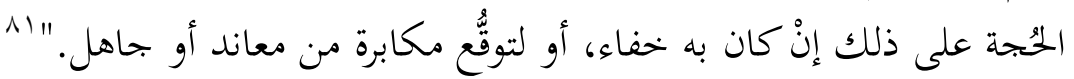

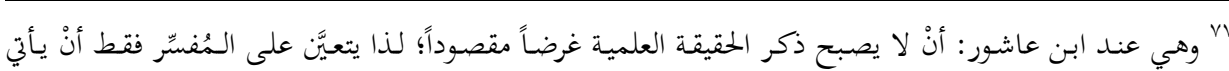

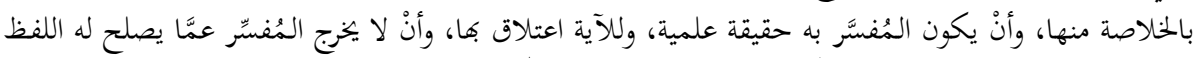

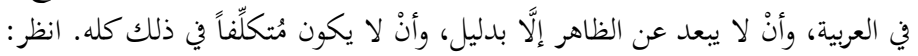

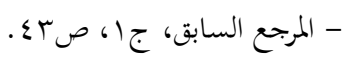

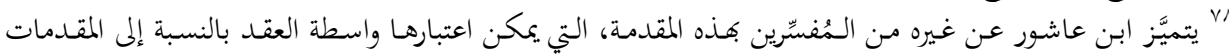

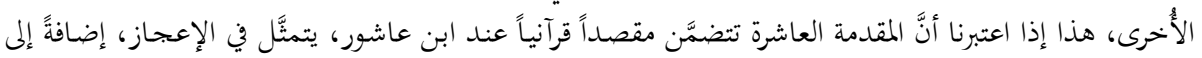

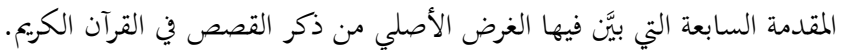

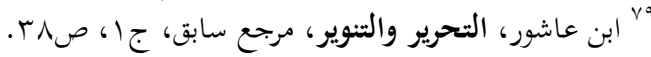

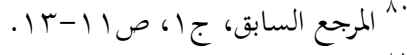

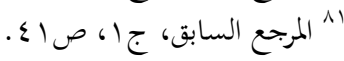




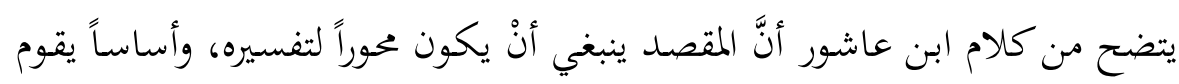

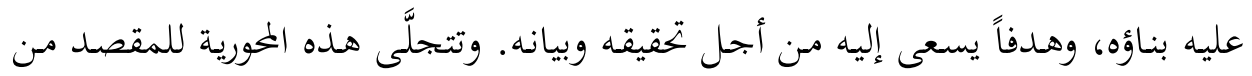

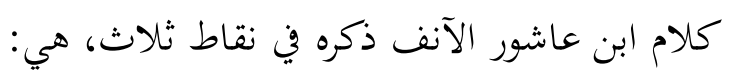

أ. بيان المراد من مقاصد القرآن بأتم بيان يحتمله المعنى، ولا يأباه اللفظ.

$$
\text { ب.بيان ما يتوقف عليه فهم المقصد. }
$$

ت. بيان ما يخدم المقصد تفصيلاً وتفريعاً مع إقامة الحُجة.

ولتحقيق هذه الأهـداف، يشترط ابن عاشور أنْ يكون "رائد المُفسِّر في ذلك أنْ

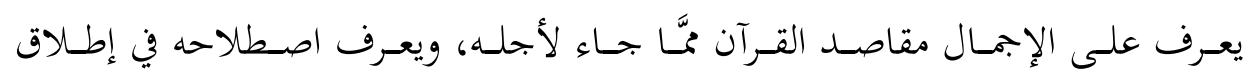

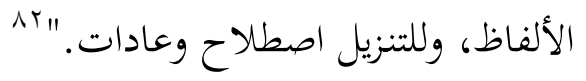

ويبدو من هذا الاشتراط أنَّ الأساس الذي ينبغي أنْ يبنى عليه التفسير هو المقاصد

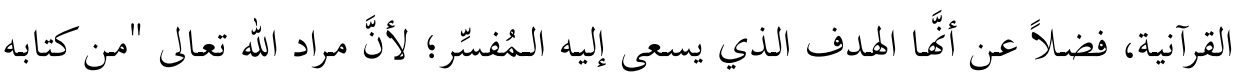

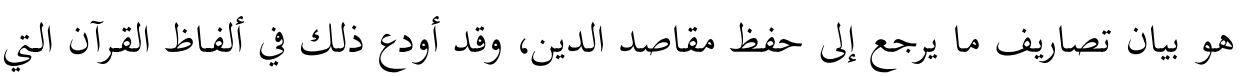

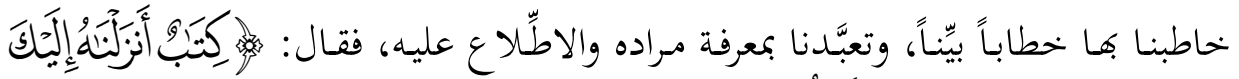

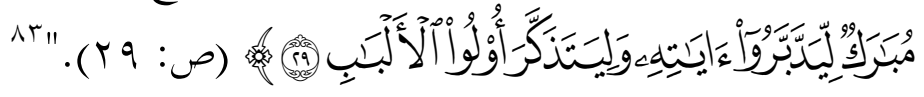

ولم يكتفِ ابن عاشور في المقدمـة الرابعة بـدعوة الـمُفسِّر إلى الالتفات إلى المقاصد

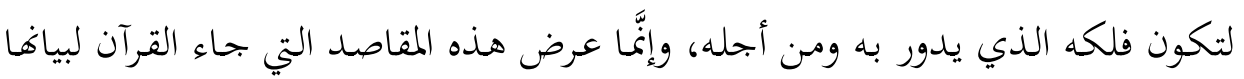

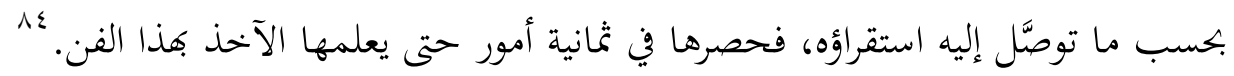

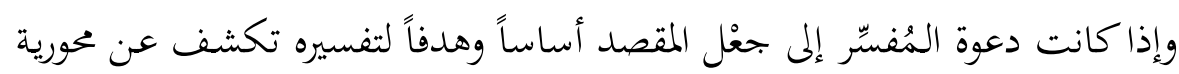

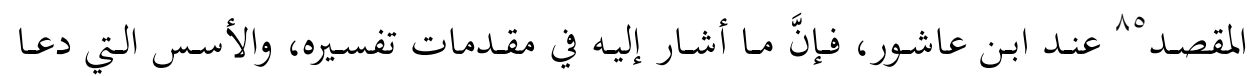

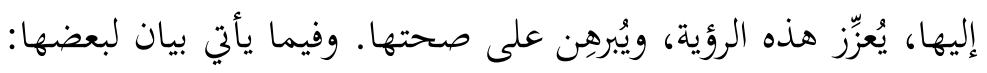

$$
\begin{aligned}
& \text { rir }
\end{aligned}
$$

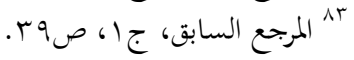

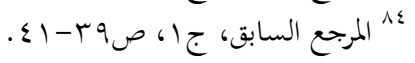




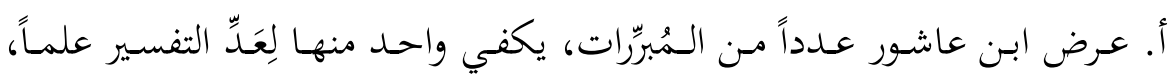

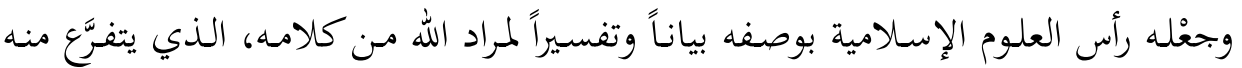

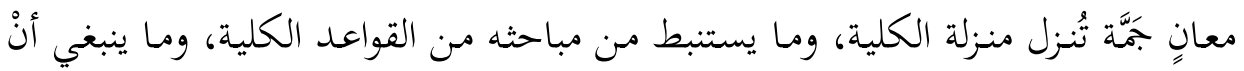

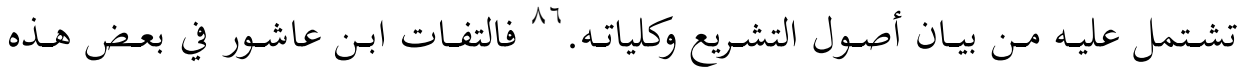

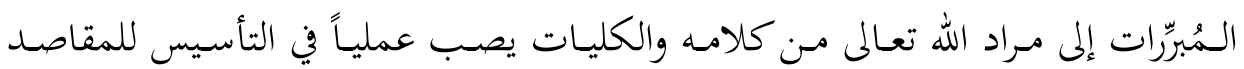

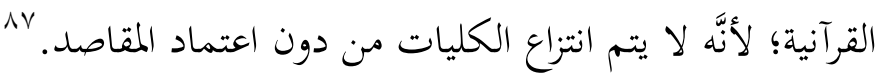
ب. ذكر ابن عاشور في تمهيد تفسيره أنَّه لن يغادر أيَّ سورة قبل بيان ما يحيط من

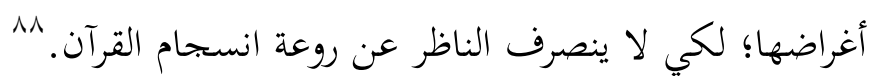
ت. جعـل ابـن عاشـور مـن ضـوابط التفسير بـالرأي الاستناد إلى مقاصـد الشـريعة وتصاريفها.

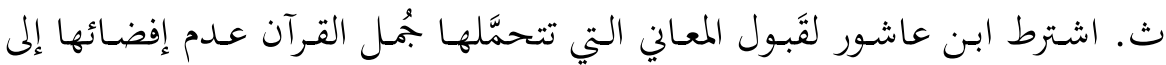

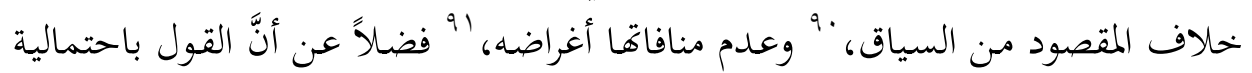

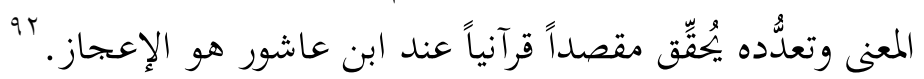

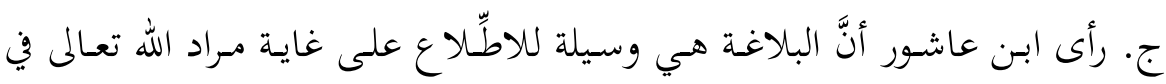
كتابه، وإثبات الإعجاز ببلاغته.

ميمكن القول مبدئياً وعلى ضوء منطوقه في المقدمة الرابعة: ينبغي على المفسر أن يلتفت إلى المقصد، وأن يجعله

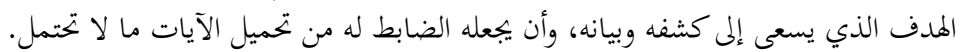

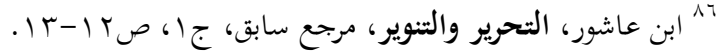

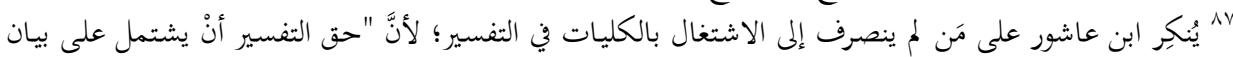

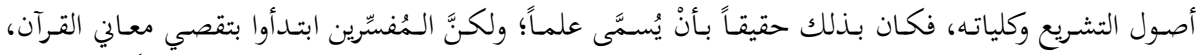

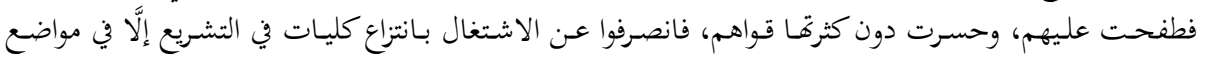
قليلة". انظر : فطلح

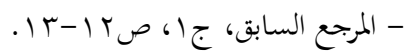

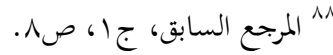

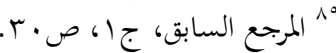

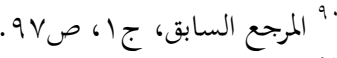

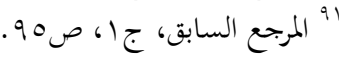

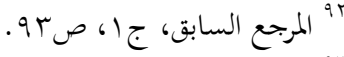

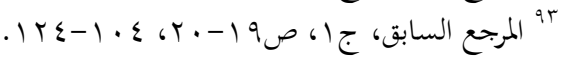




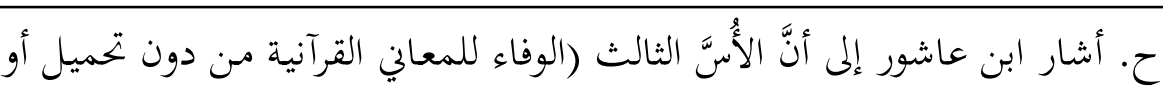

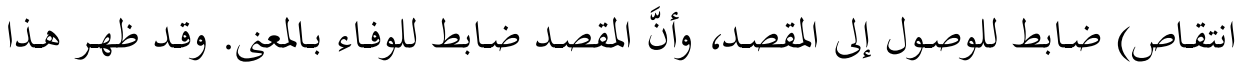

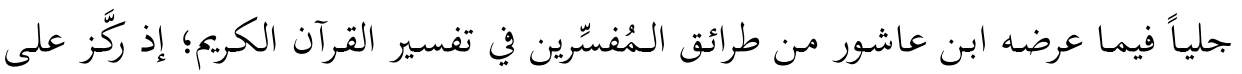

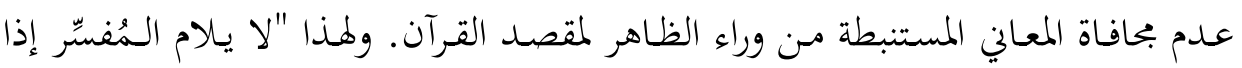

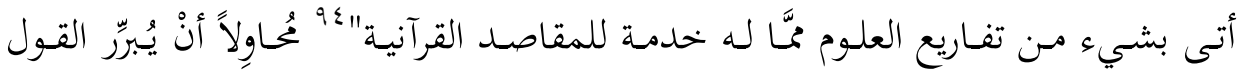
بالتفسير العلمي على ضوء المقاصد.

خ. استحضـر ابن عاشور في المقدمة السـابعة أغراض القـرآن الكريم مـن القصص،

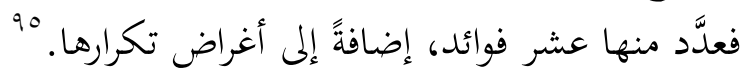

د. بيَّن ابن عاشور في المقدمة الثامنة محورية الغرض من ترتيب الآيات بعضها عقب

ذ. جعـل ابـن عاشـور المقدمـة العاشـة لبيـان مقصـد أصـلي مـن مقاصـد القـرآن هـو

ر. تضمَّن تفسير ابن عاشور حضوراً مُتميِّاً للمقاصد القرآنية. 91

\section{ثانياً: مفهوم المقصد عند ابن عاشور}

من النادر أنْ تخلو صفحة من صفحات "التحرير والتنوير" مـن ذكر لفظ "المقصد"

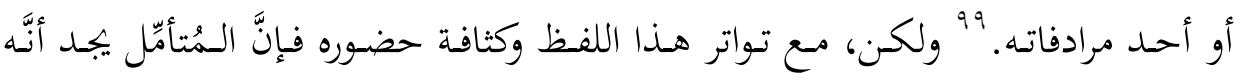

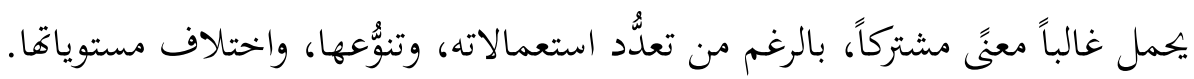

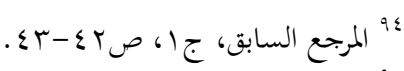

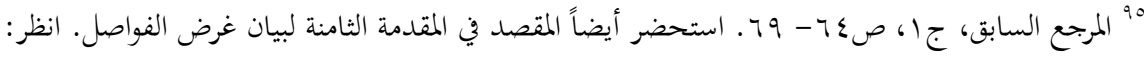

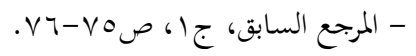

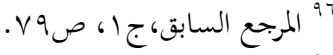

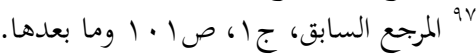

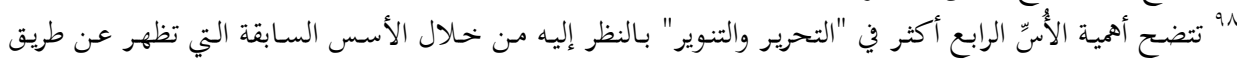

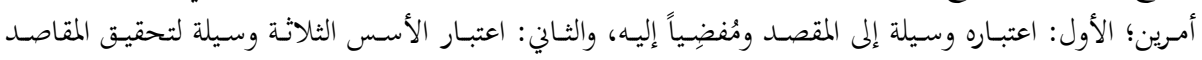




\section{1 ا ـ تعريف مقاصد الشريعة عند ابن عاشور وعلاقتها بمقاصد القرآن:}

يظهر من تتبُعُع استعمال ابن عاشور للفظ "المقصد" في تفسيره أنَّهَ لمُ يُقدِّم له تعريفاً،

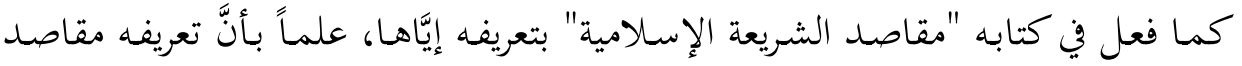

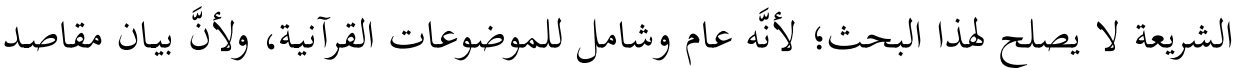

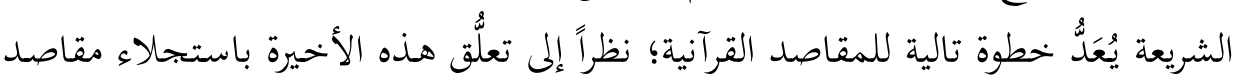

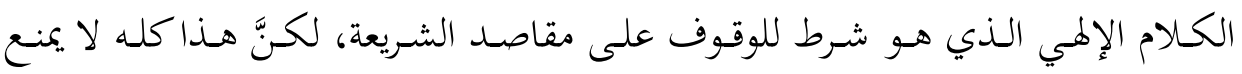
الاستئناس بتعريف ابن عاشور لمقاصد التشريع العامة.

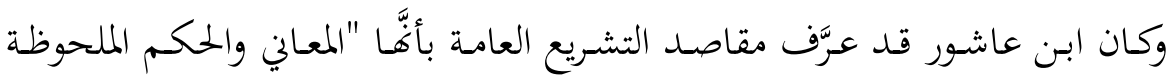

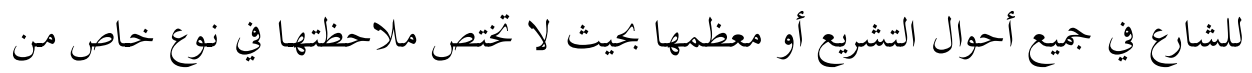

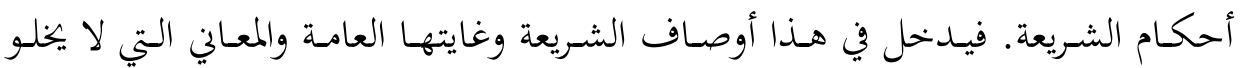

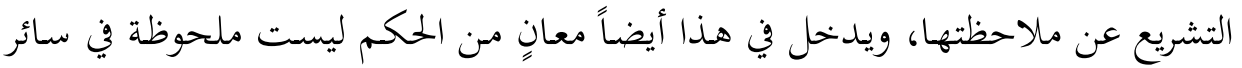

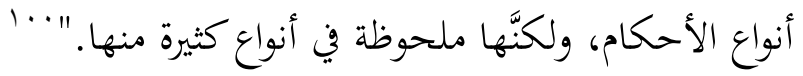

وهـذا التعريف لا يصلح في بحثنا لاختلاف بحال كلِّ منهما عن الآخر؛ فمقاصد

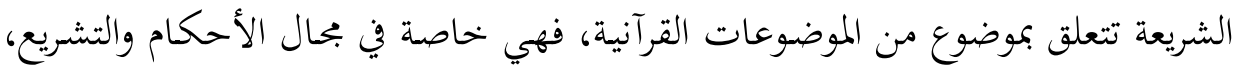

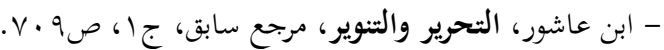

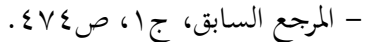

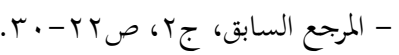

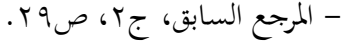

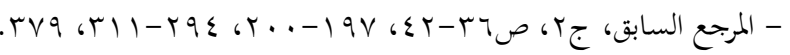

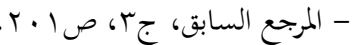

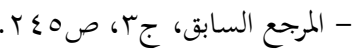

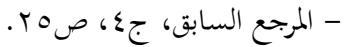

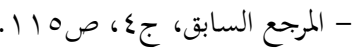

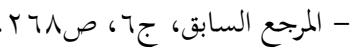

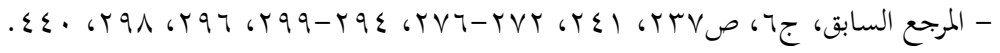

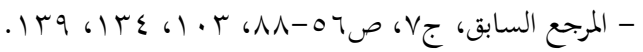

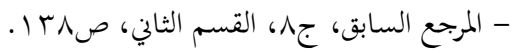

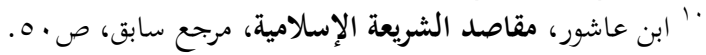


وهـذا مـا صرَّح بـه ابـن عاشـور في مقدمـة كتابـه "مقاصـد الشريعة الإسـلامية"؛ إذ قـال:

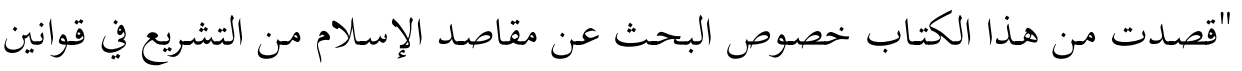

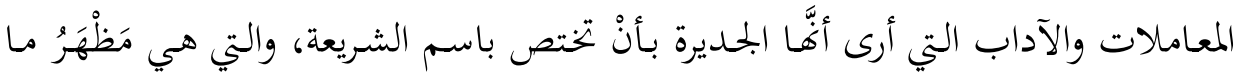

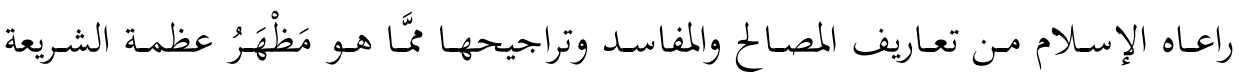

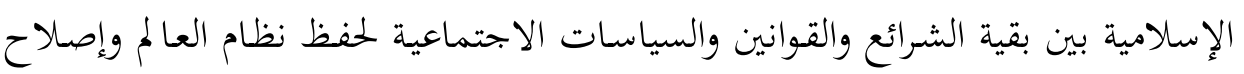

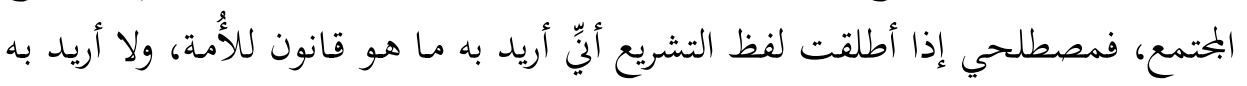

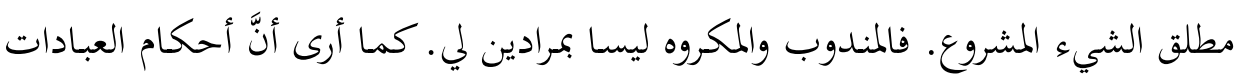

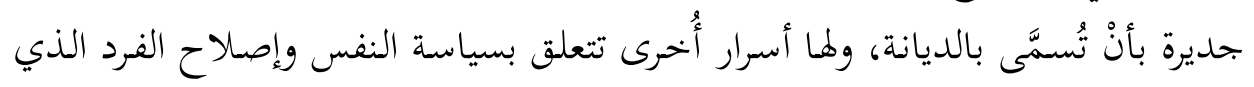

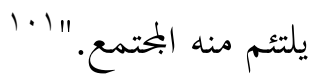

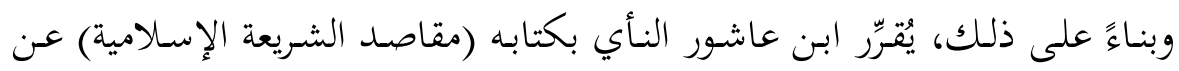

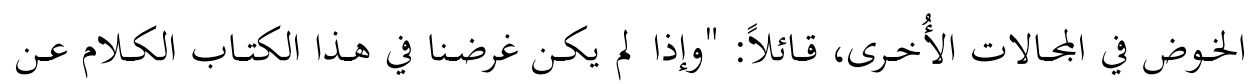

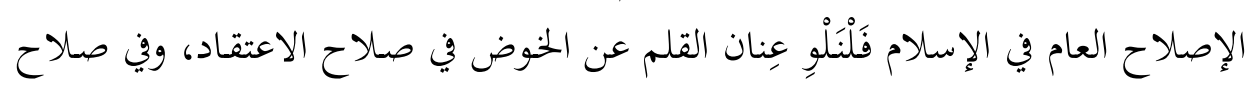

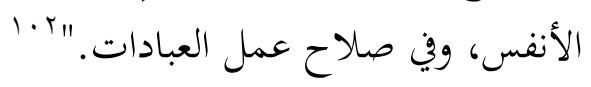

ولهذا يتعيَّن علينا أنْ نتتبَّع استعمال ابن عاشور للفظ "المقصد" في شعاب تفسيره؛

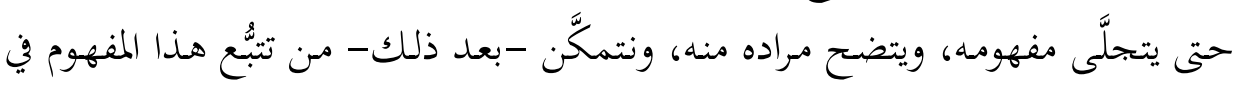

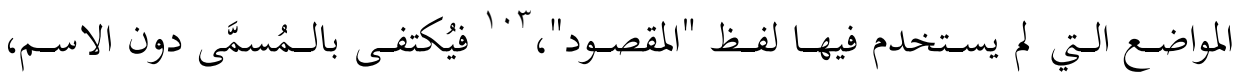

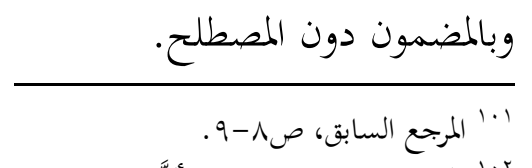

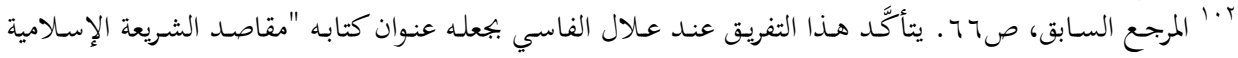

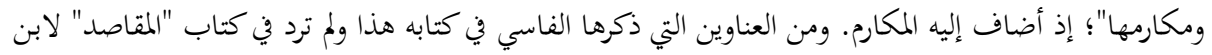

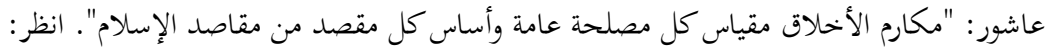

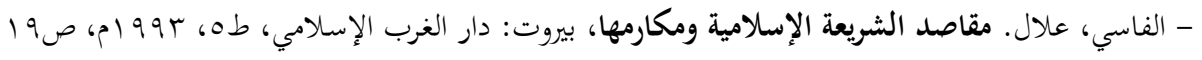

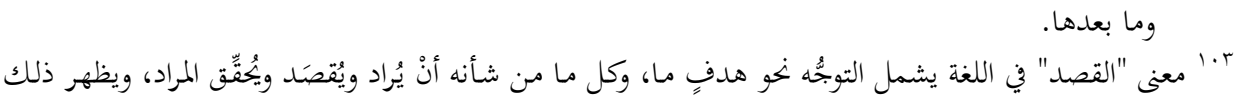

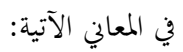
- القصد: استقامة الطريق.

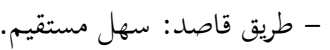
- القصد: الاعتماد والأمّ. 


\section{r r r تعريف المقصد:}

استخدم ابن عاشور لفظ "المقصود" في بيان مقصد من آيات متتالية، نَصَّت على

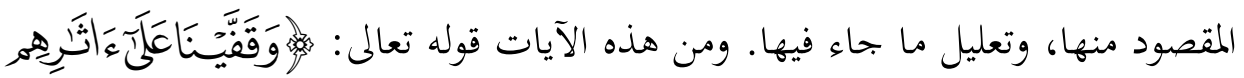

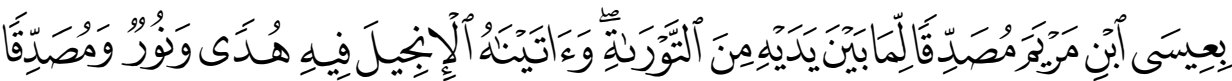

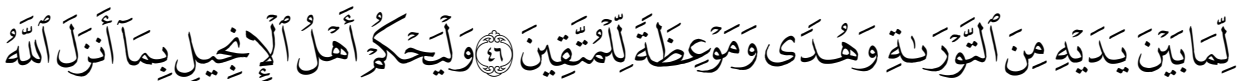

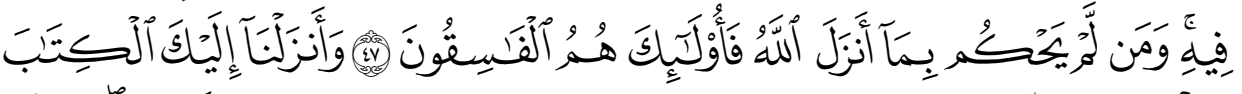

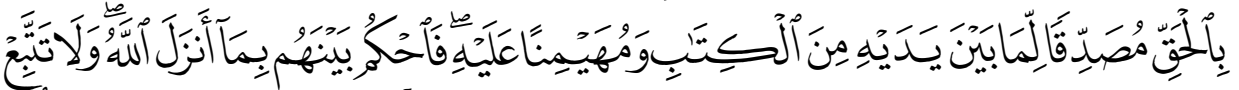

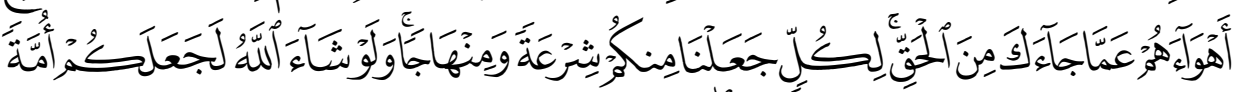

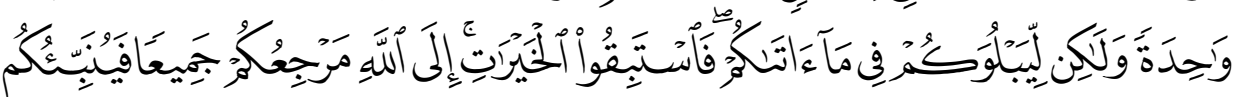

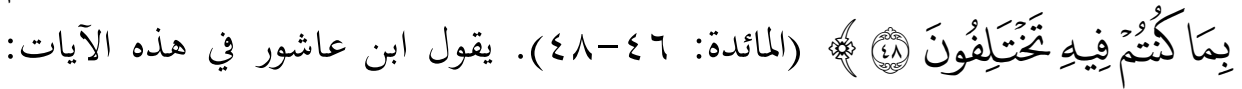
"وجالت الآيات المتقدمة جولة في ذكر إنزال التوراة والإنجيل، وآبت منها إلى المقصود بهون

$$
\begin{aligned}
& \text { - القصد: إتيان الشيء، قصدت قصداً: نحوت نحوه. } \\
& \text { - القصد في الشيء: خلاف الإفراط. } \\
& \text { - القصيد من الشعر : ما تم شطر أبياته، سيّيّي بذلك لكماف الفماله وصحة وزنه. }
\end{aligned}
$$

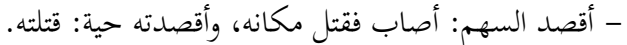

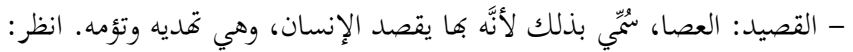

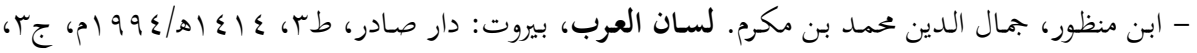

ص صنr

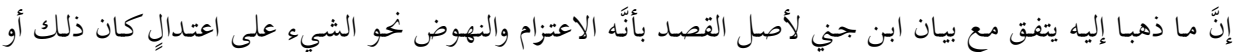

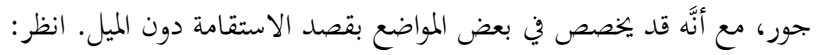

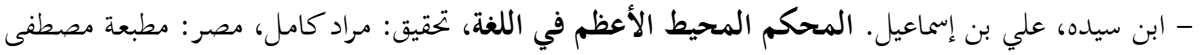

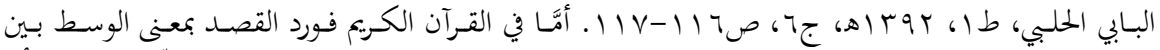

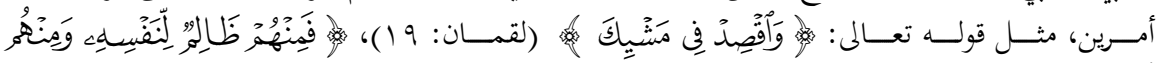

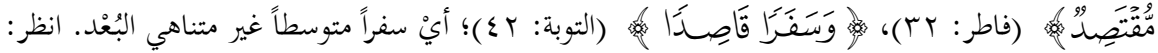

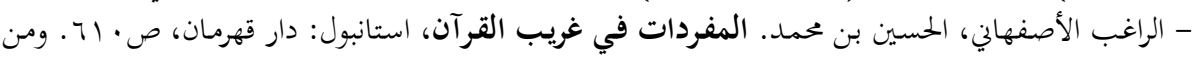

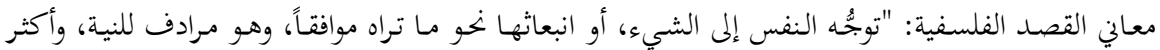

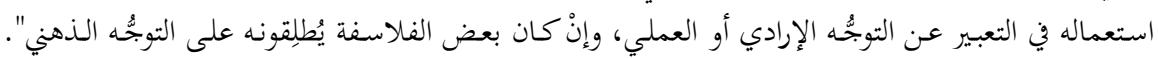




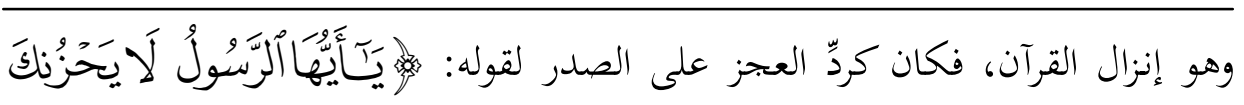

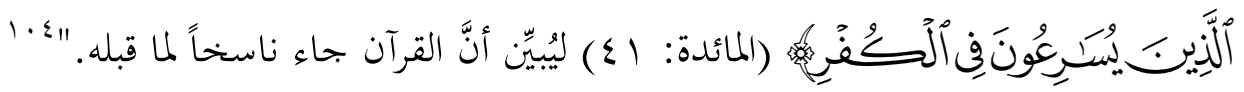
والمهُلاحَظ على هذا المثال -حسب الظاهر - أنَّ المقصد يشمل مستويين؛ الأول:

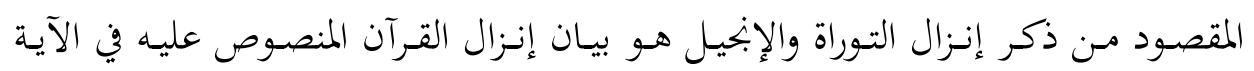

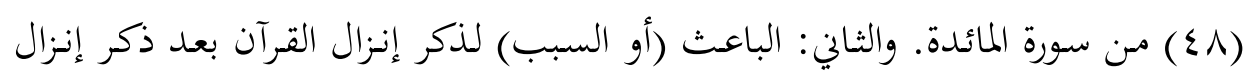

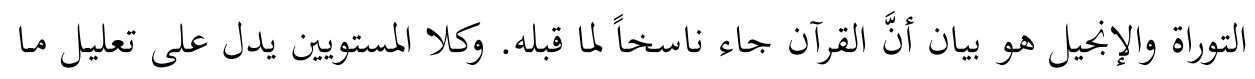

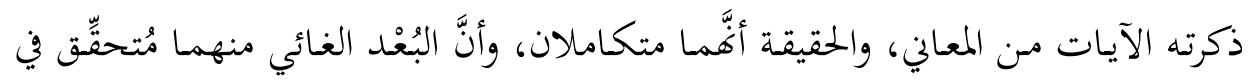
المستوى الثاني.

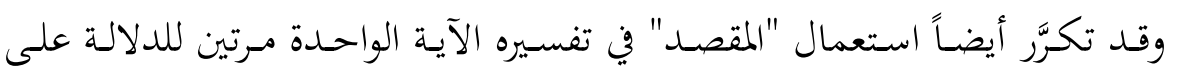

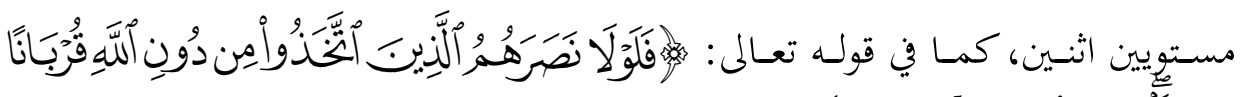

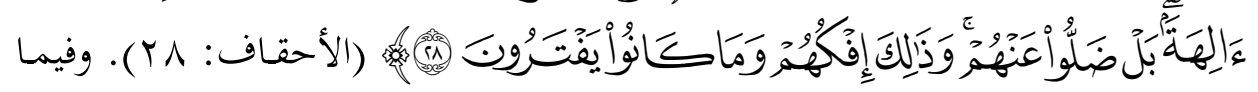
يأتي تفصيل وبيان لكلا المستويين:

المستوى الأول: التأثير والإقناع، وفيه يقول ابن عاشور: "المقصود توجيه التوبيخ إلى لي لئي

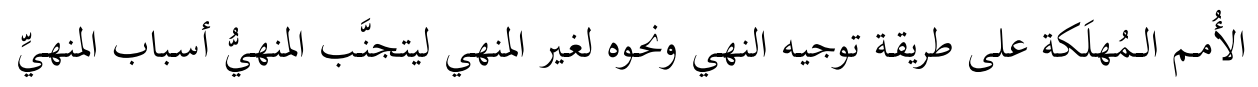

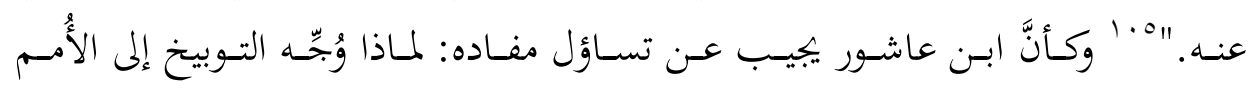

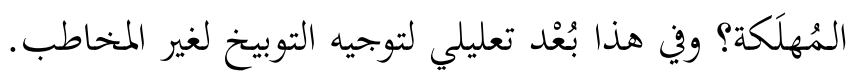

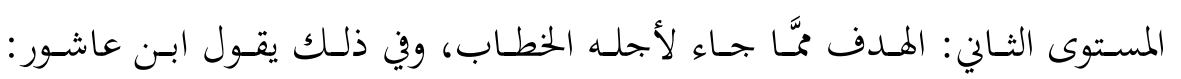

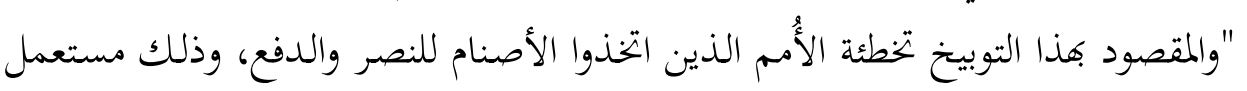

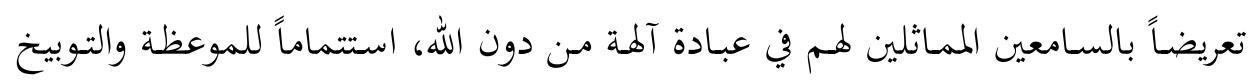

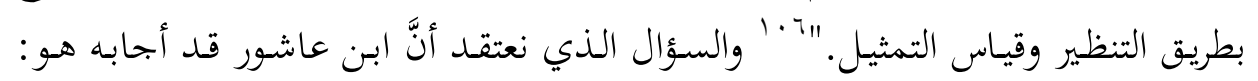

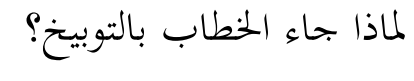

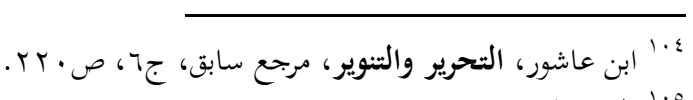

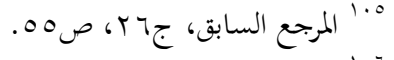

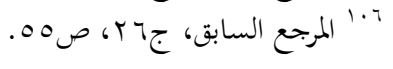




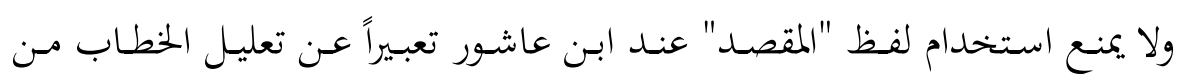

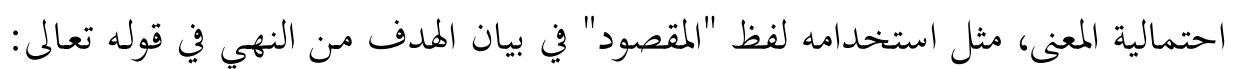

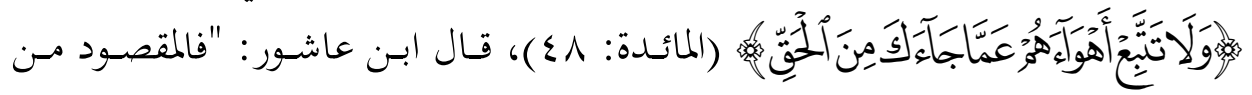

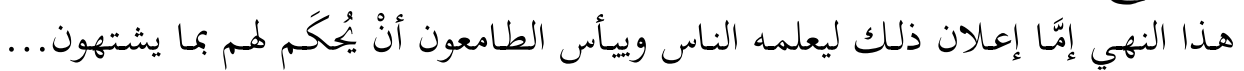

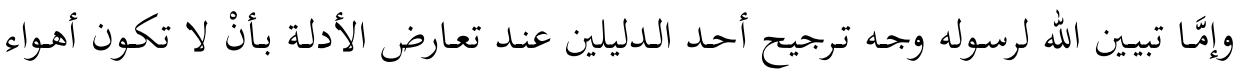

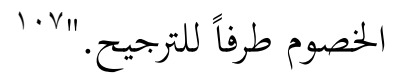

وقد استعمل ابن عاشور لفظ "المقصد" مرات عدَّة في الآية الواحدة؛ لبيان الباعث

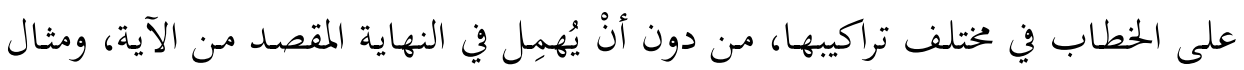

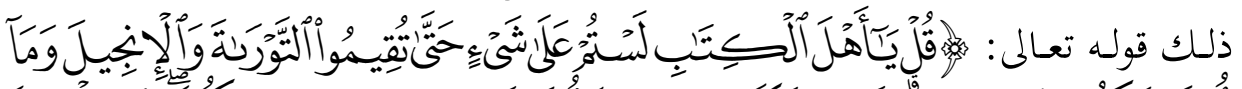

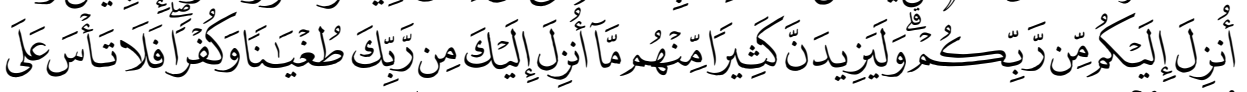

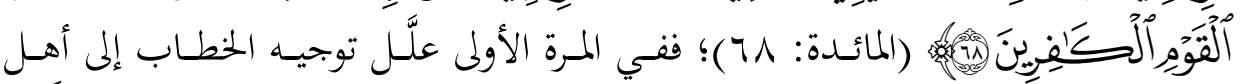

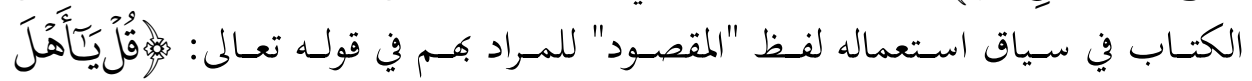

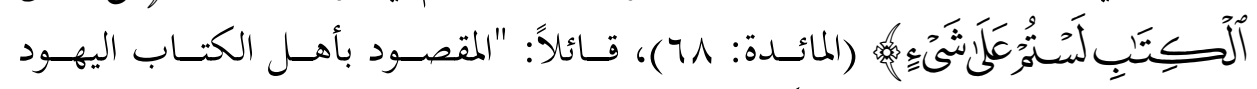

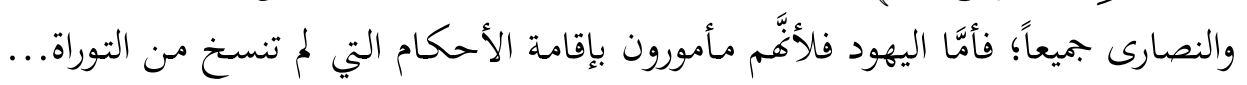

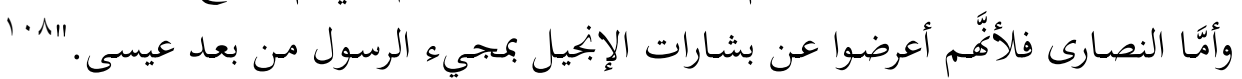

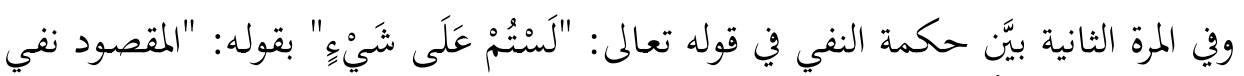

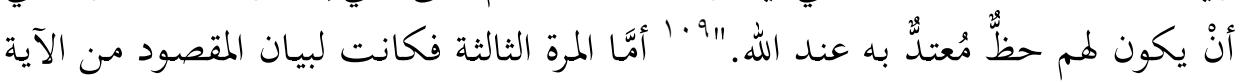

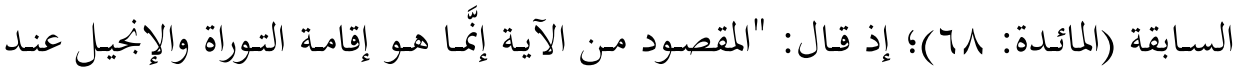

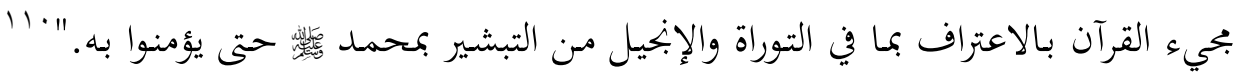

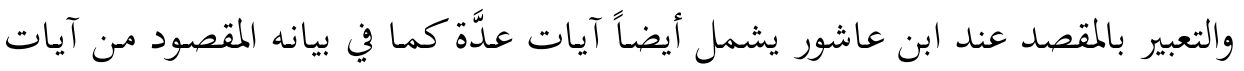

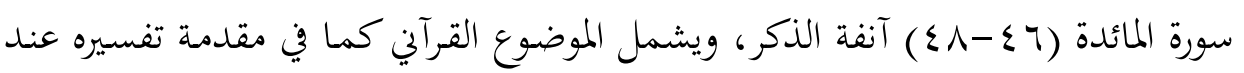

تلخيصه المقاصد الأصلية.

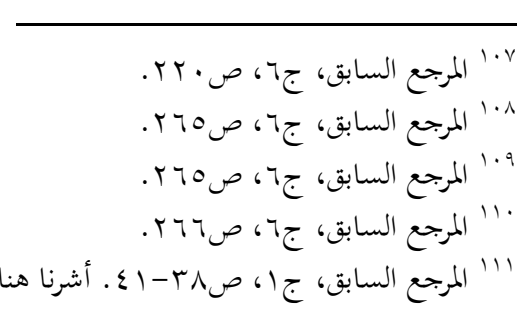


واسـتعمل ابـن عاشـور أيضـاً لفـظ "المقصـد" لبيـان المقاصـد البلاغيـة، مثـل تقصسيده

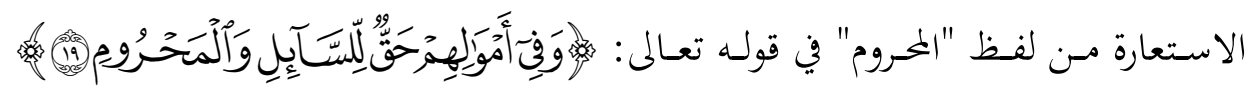
(الـذاريات: 9 (1)؛ إذ قـال: "والمقصـود مـن هـذه الاستعارة ترقيـق النفـوس عليـه، وحـث

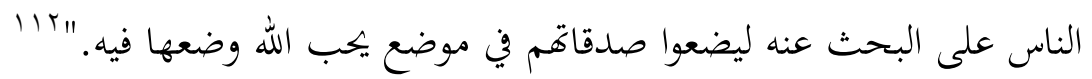

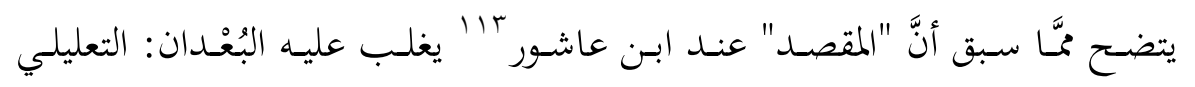
والغائي لمضامين الخطاب الإلهي؛ سواء أكانت خبراً، أم إنشاءً في مستويات متعددة.

\section{ب. ألفاظ مرادفة للفظ "المقصد":}

استـخدم ابـن عاشـور لفظظ "الغـرض" رديفـاً لمعنى "المقصـد" مـن حيـث المفهـوم. عال

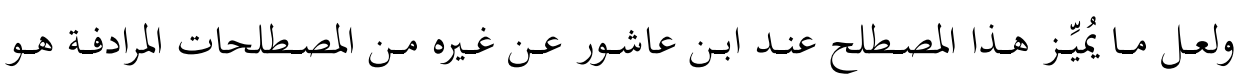

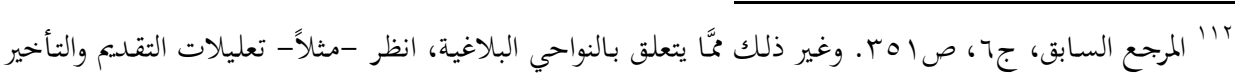

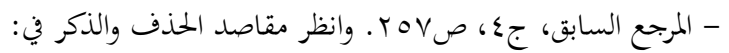

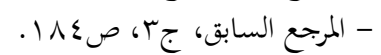

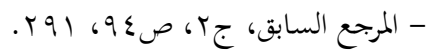

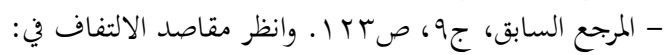

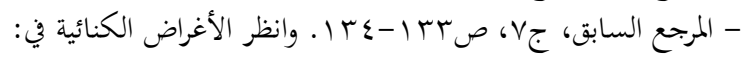

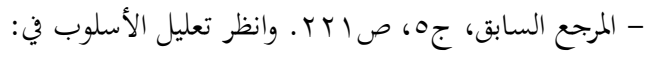

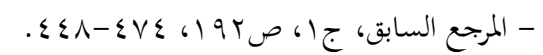

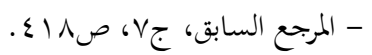

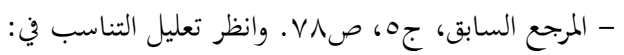

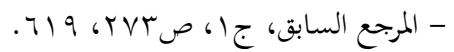

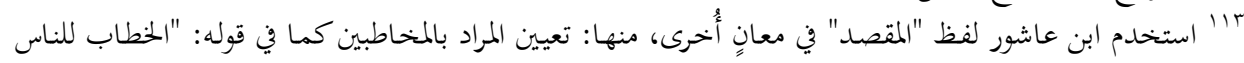

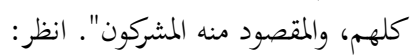

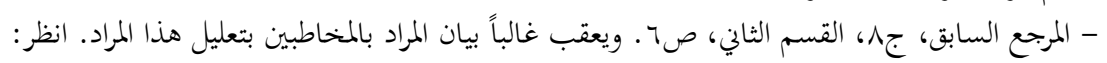

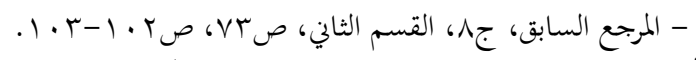

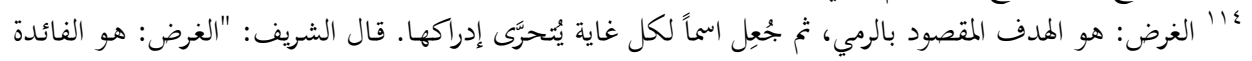

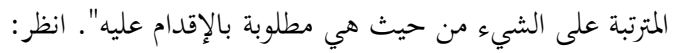

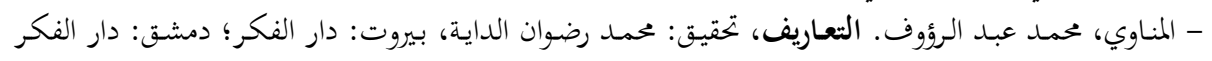

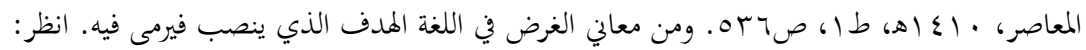

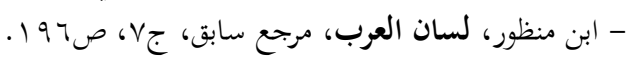


استعماله غالباً للدلالة على المقاصـد الكليـة العامـة. 110 ويظهر هـا جلياً عند قوله في

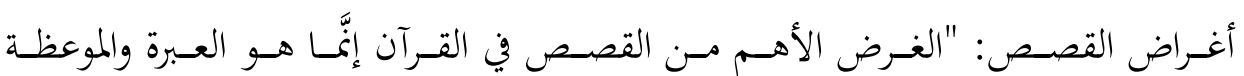
والتأسي." "ال" ويقول في بيان هدف سورة الأعراف الكلي: "الغرض من السورة إبطال ما كان عليه مشركو العرب من الشرك وتوابعه من أحوال دينهم الجاهلي.. II"

واستعمل ابن عاشور أيضـاً لفظظ "الغرض" للدلالمة على مقصـد الآيتين العـام عند

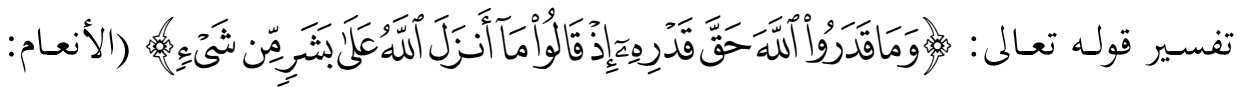
19)؛ فذكر "واو العطف في صدر هذه الجملة ينادي على أهَّا نزلت متناسقة مع الجمال

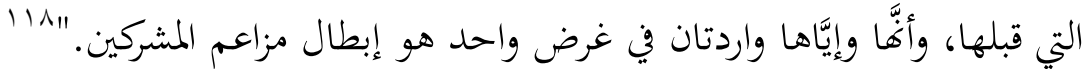

وفي هذا السياق، عبَّ ابن عاشور عن مضمون المفهوم المقاصدي بوجه عام والغرض خاصةً بألفاظ معينة، تظهر واضحة جلية في النصين الآتين:

مايَّز ابن عاشور بين الفائدة والغاية والغرض المتعلق بالفعل، فقال: "اعلم أنَّ الأثر المترتب على الفت الفعل إذا نُظِر إليه

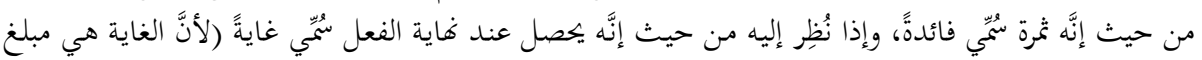

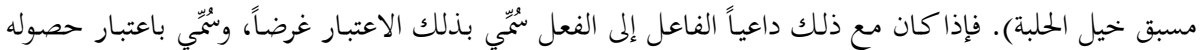

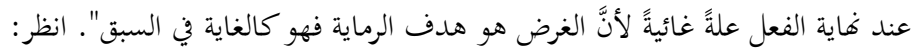

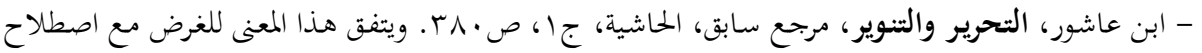

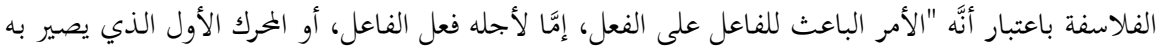

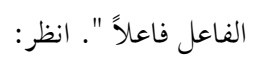

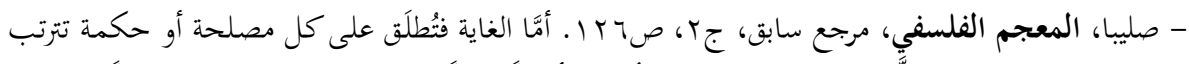

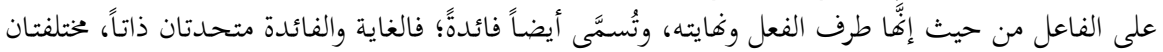

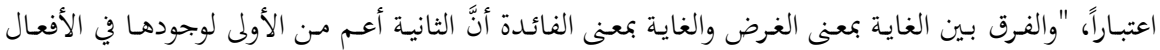

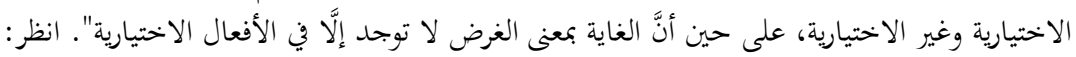

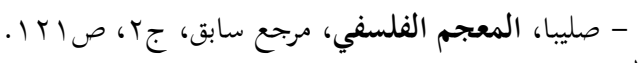

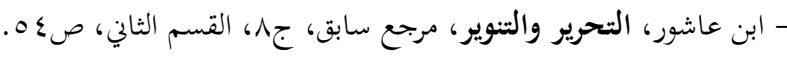

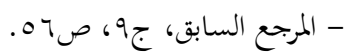

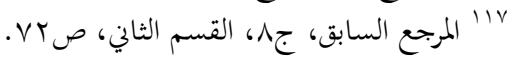




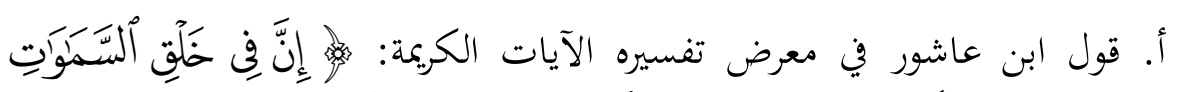

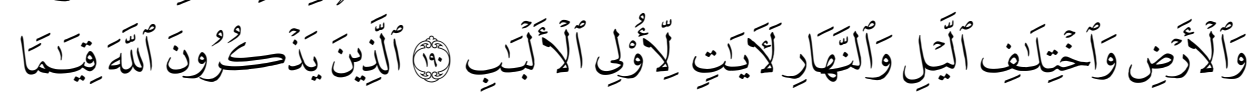

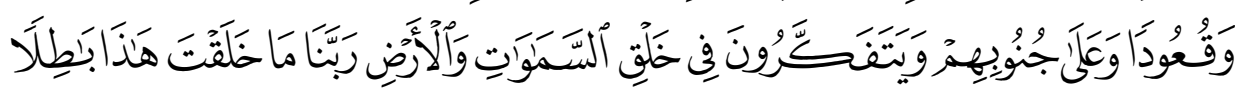

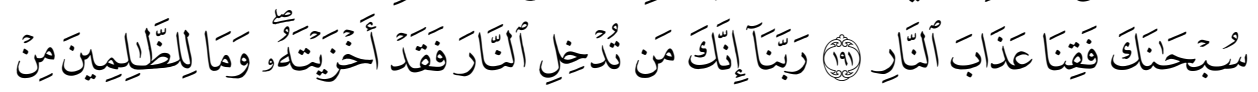

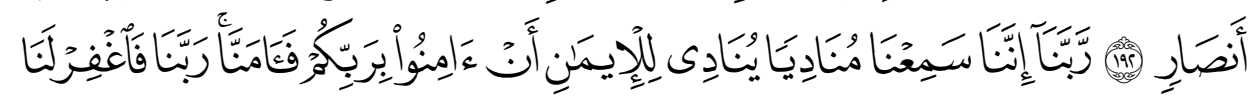

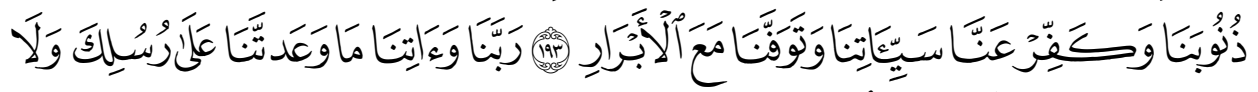

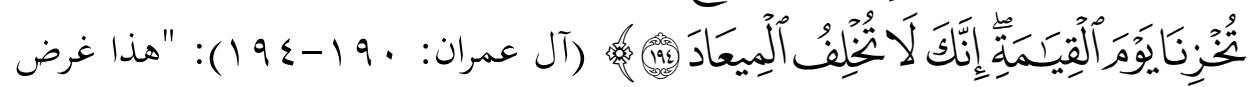

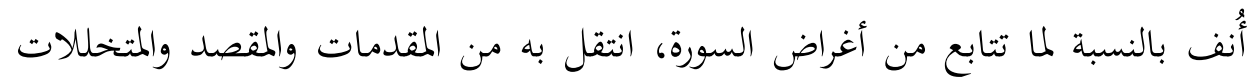
بالمناسبات إلى غرض جديد هو الاعتبار بخلق العوالم وأغراضها والتنويه بالذين يعتبرون

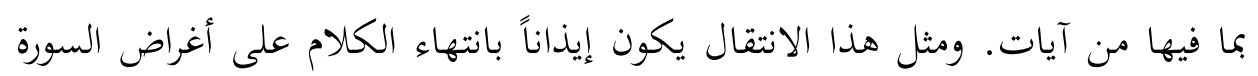

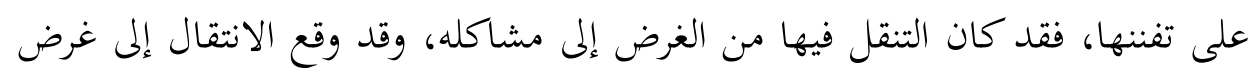

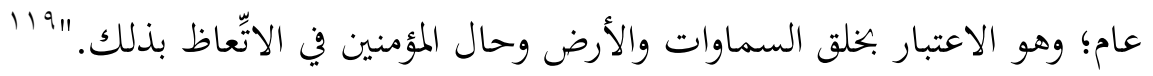

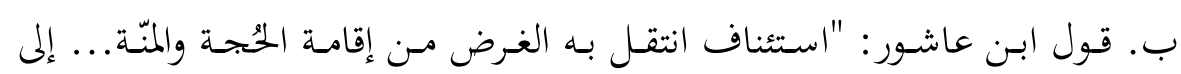

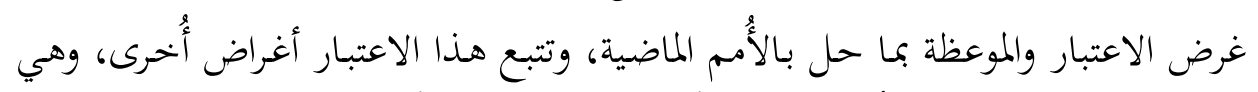

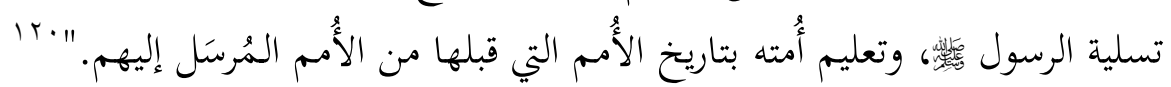

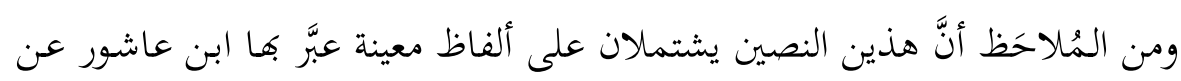

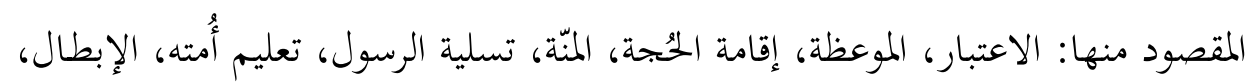

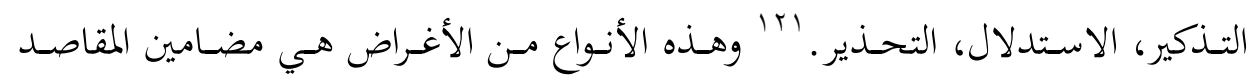
الأصلية التي ذكرها ابن عاشور في مقدمة تفسيره.

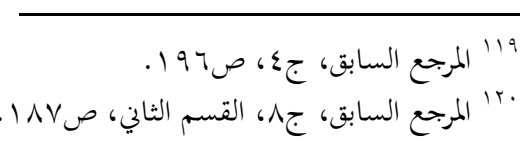

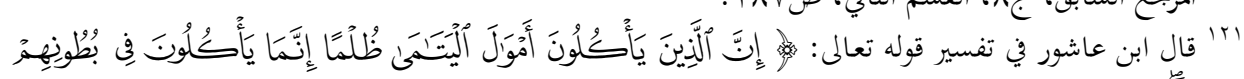

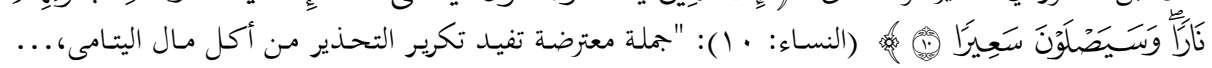

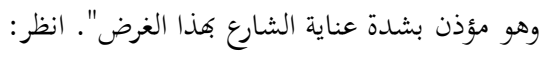

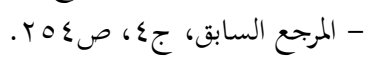




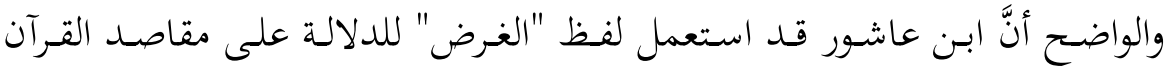

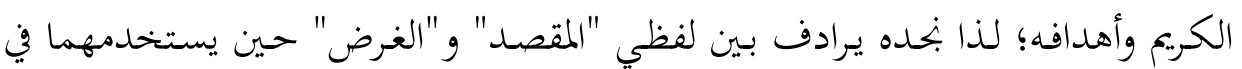

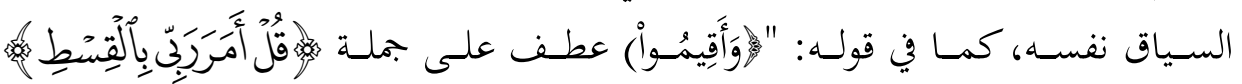

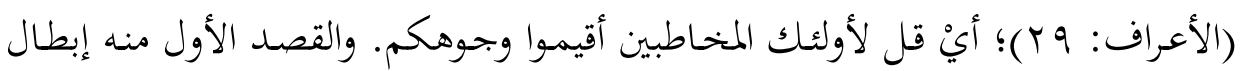

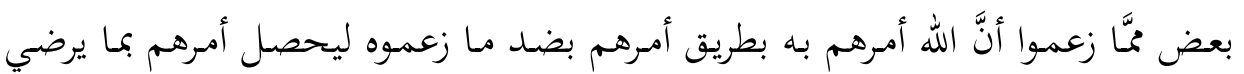

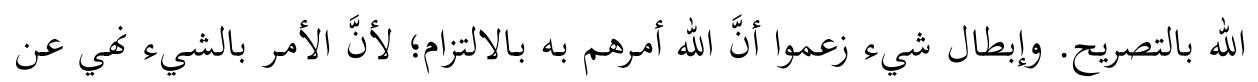

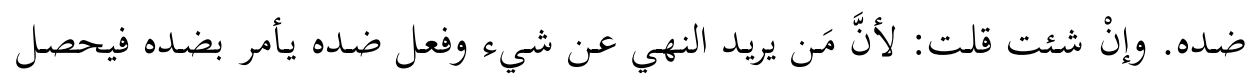

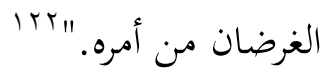

فسَمَّى كَّلًَ من المقصد الأول والمقصد الثاني غرضاً، ولكنَّ هذا ليس مطرداً؛ فقد

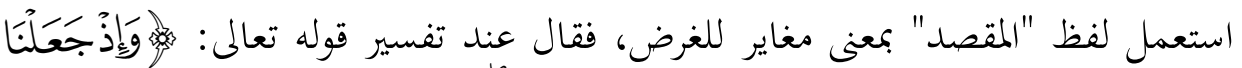

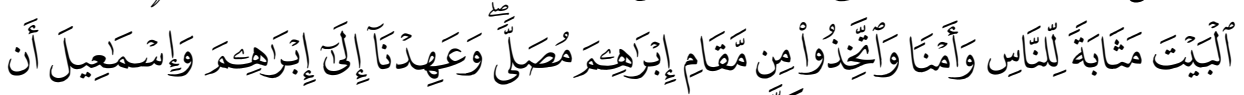

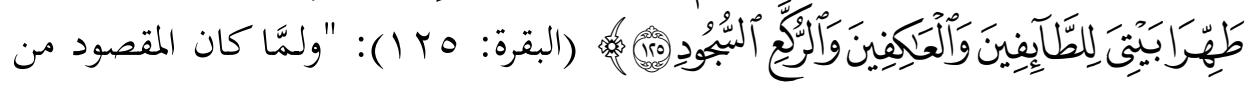

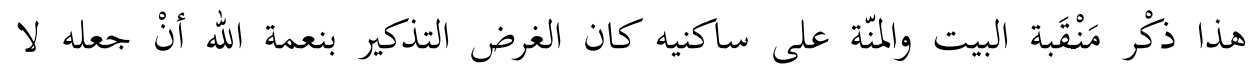

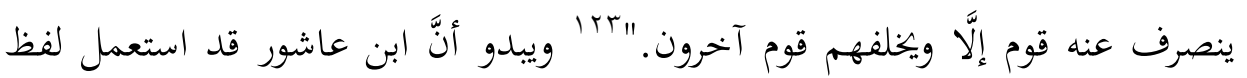

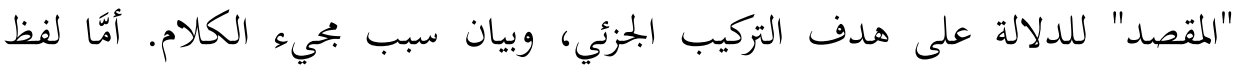

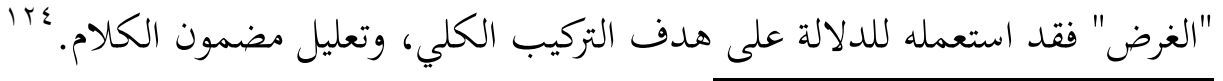

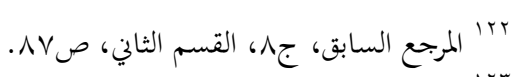

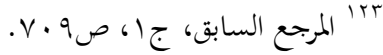

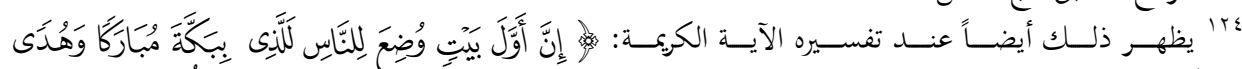

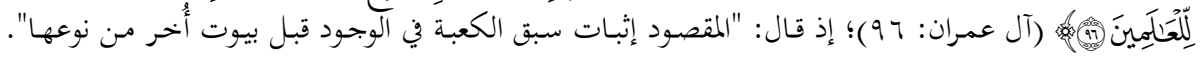

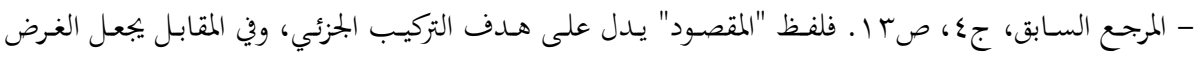

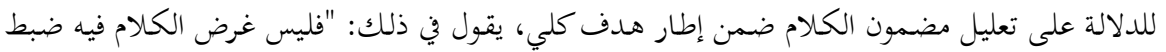

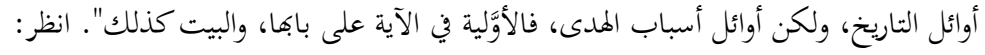

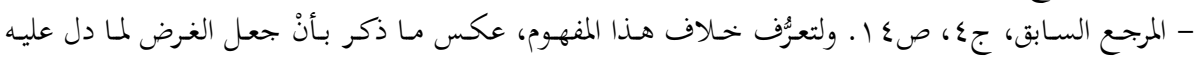

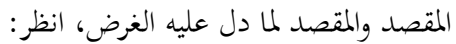

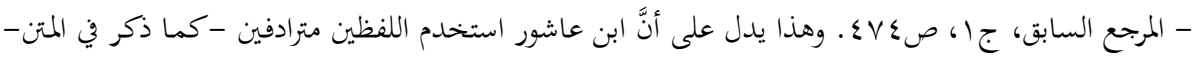

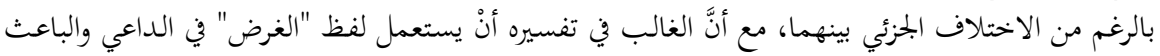

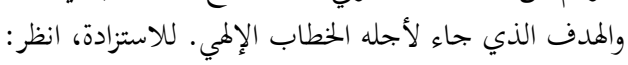


وعند إنعام النظر في هذه الاستعمالات بجد أهَّا تصدِّ في بيان المفهوم المقاصدي

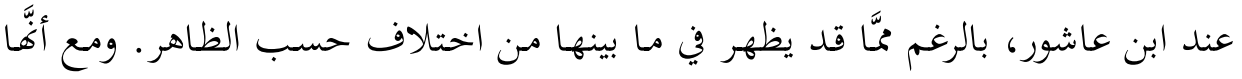

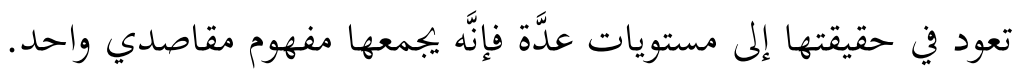

ونشير هنا إلى أنَّ هذا المفهوم للمقاصد عند ابن عاشور لا يختص بلفظي "المقصد"

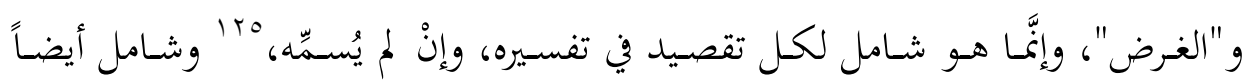

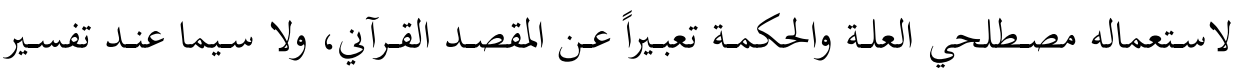

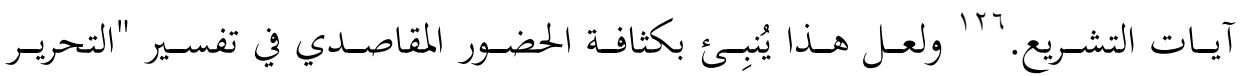
والتنوير"؛ مـا يـدفعنا إلى التسـاؤل عـن علاقـة المفهـوم المقاصـدي بلفظظ "المعنى "عند ابن عاشور لقد استعمل ابن عاشور مصطلح "المعنى" غالباً للدلالة على شرح المفردات

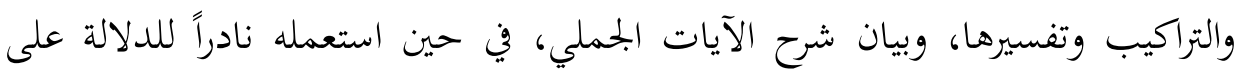

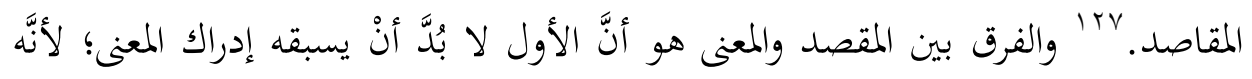

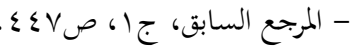

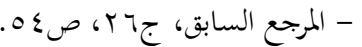

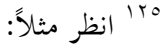

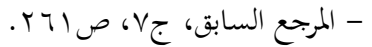

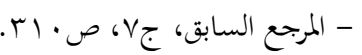

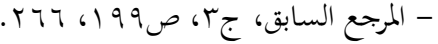

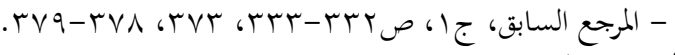

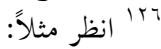

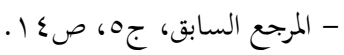

$$
\begin{aligned}
& \text {.r. } 7
\end{aligned}
$$

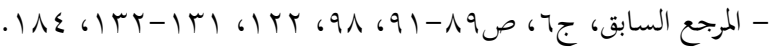

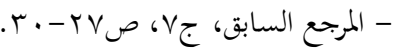

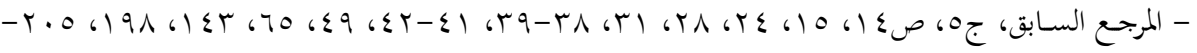

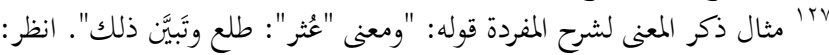

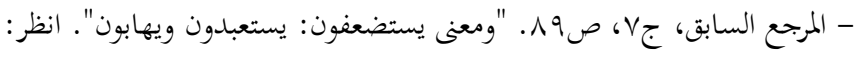

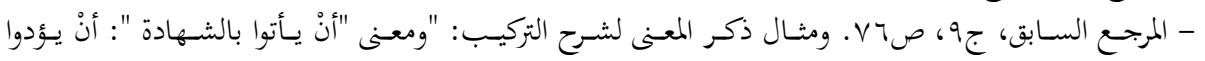

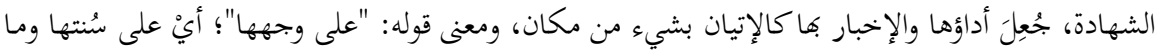




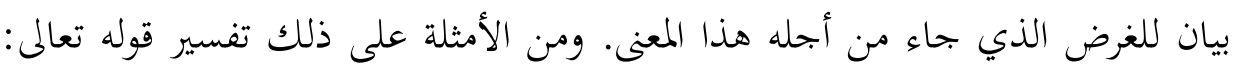

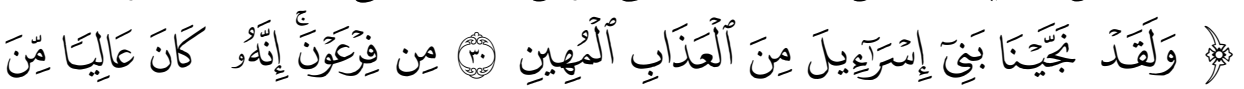

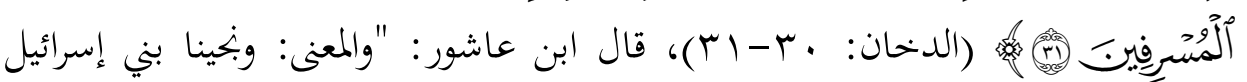

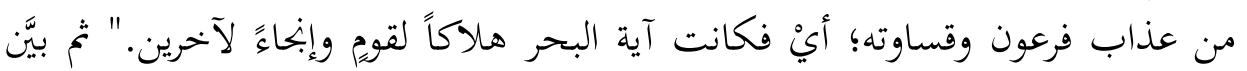

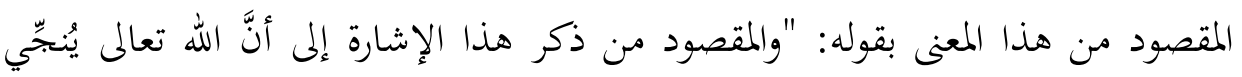

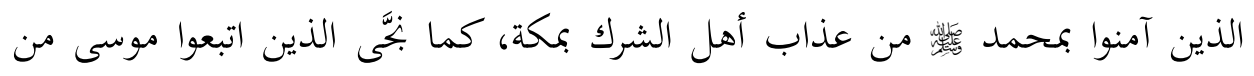

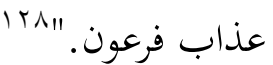

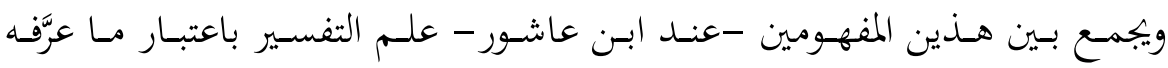

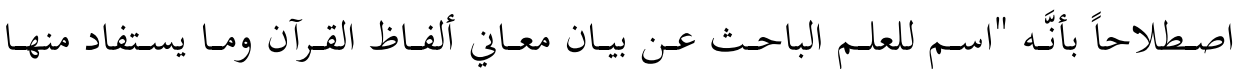

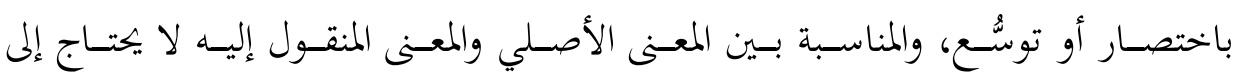
تطويل."1ra"

وهـذا التعريـف يوضـح هـدفين لعلـم التفسـير حسبـ الظـاهر؛ الأول: بيـان معـاني

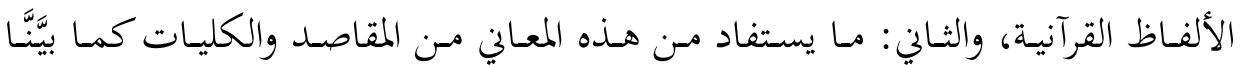

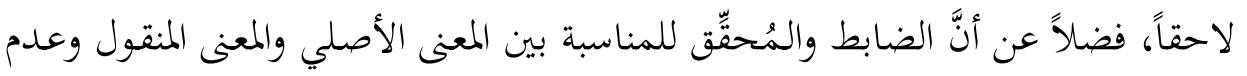

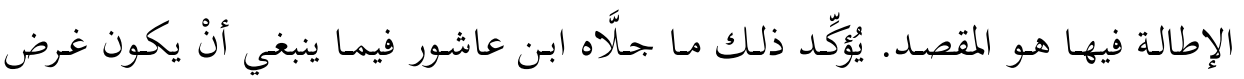

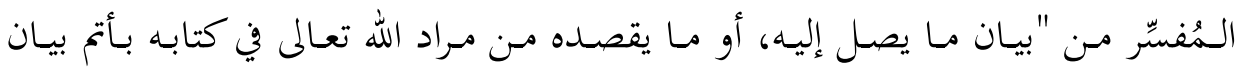

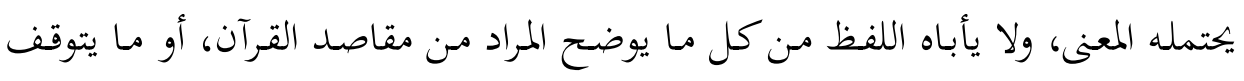

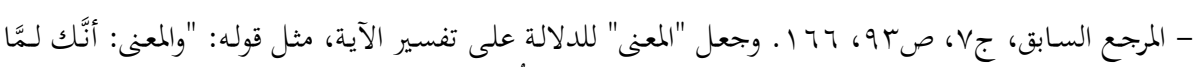

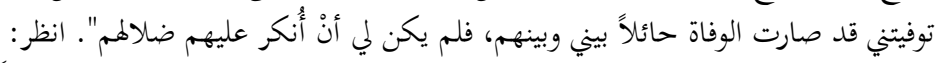

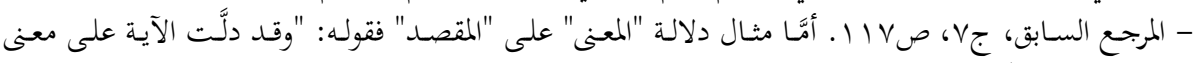

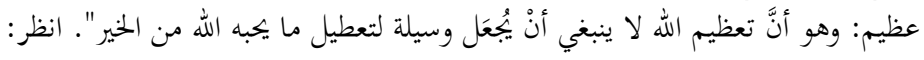

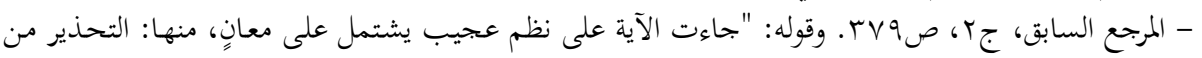

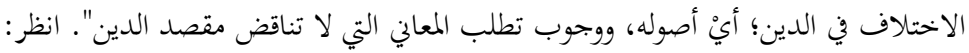

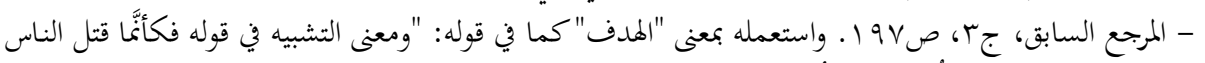

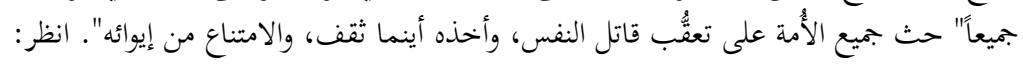

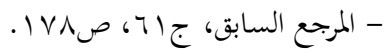

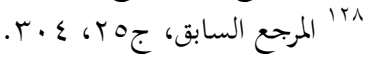

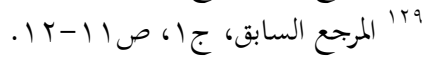




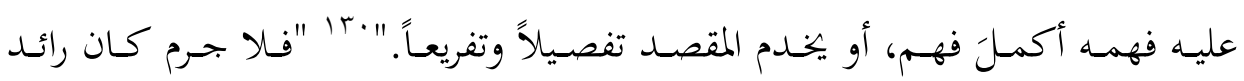

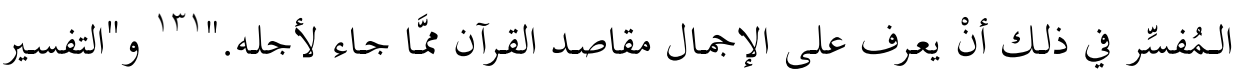

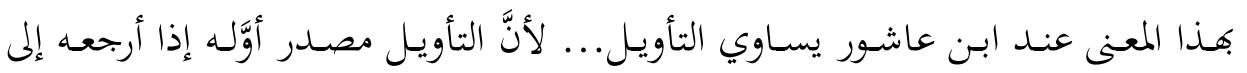

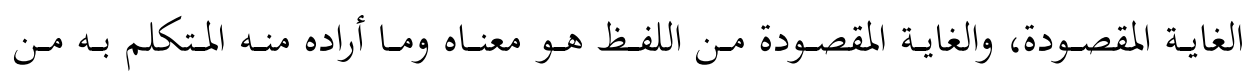

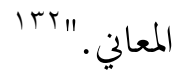

\section{خاتمة:}

من المُملاحَظ أنَّ ابن عاشور أدرك أسباب تأخُّر علم التفسير، فحاول في مقدمات

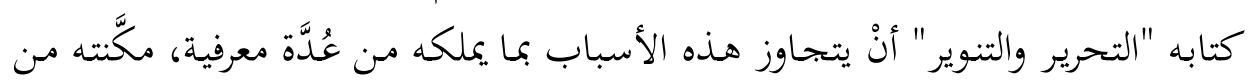
تقديم رؤية إصلاحية، ظهرت منطلاقاتا في أمور أربعة، هي: تعدُّد المعاني القرآنية، وإبراز

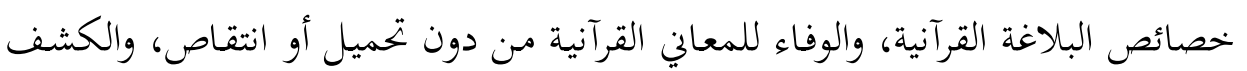

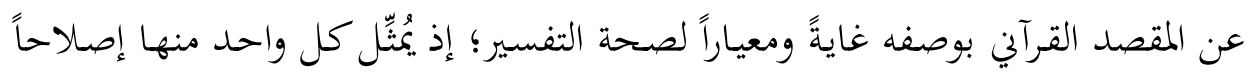

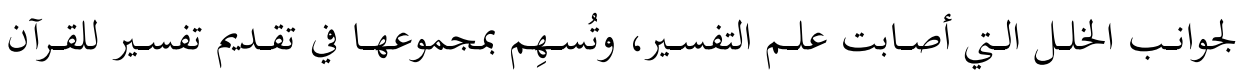

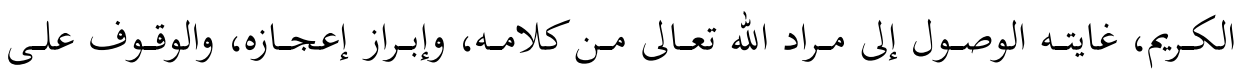

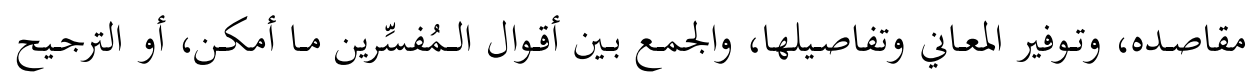

بينها.

وقد تَبسيَّن لنـا أنَّ المحور الذي تدور في فلكه هـذه الأسس هـ الأُسٌ الرابع (المقصد القرآني)، فهو عند ابن عاشور ما ينبغي أنْ يسعى إليه المُفسِّر لتجليته، وأنْ يحتكم إليه

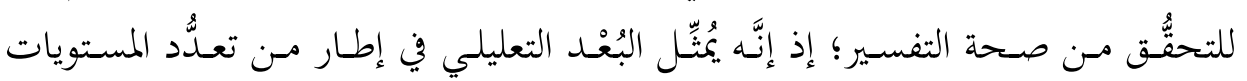

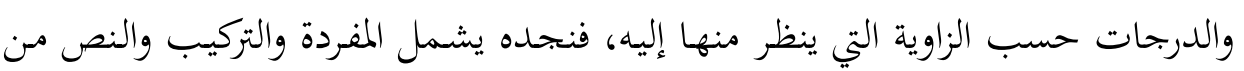

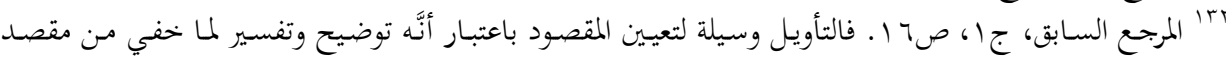

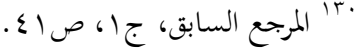

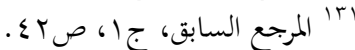

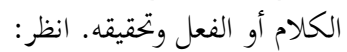

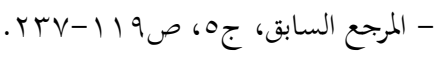

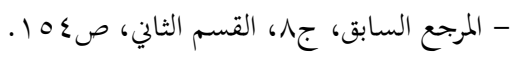




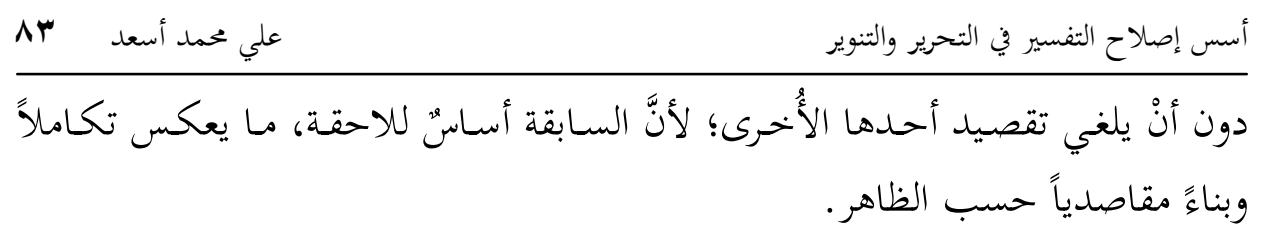

ولهذا فقد عملنا على تحديد المراد بالمقاصد القرآنية عن طريق بيان مستويات الخطاب القرآي التي يمكن حصرها في ثلاثة مستويات:

الأول:ما جاء به القرآن الكريم من مضامين؛ سواء أكانت خبراً أم إنشاءً، وقد تكون

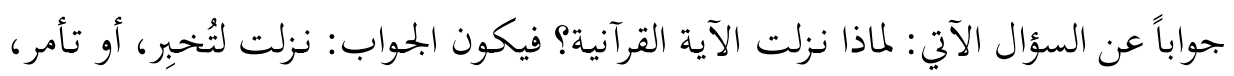
أو تنهى.

الثاني: العلل والحكم والمعاني المستنبطة من الخطاب، وقد تكون جواباً للسؤال الآتي:

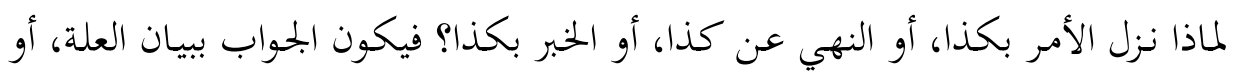
الحكمة، أو المعنى، أو العبرة.

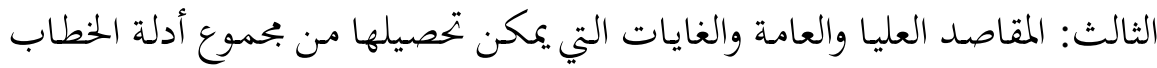

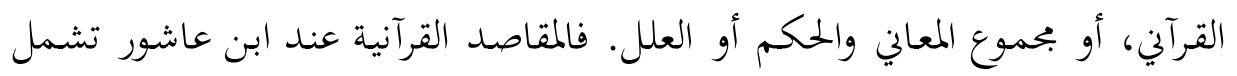

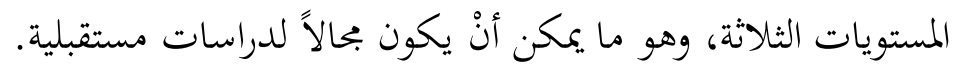

